\title{
Taxonomic Characterization and Secondary Metabolite Analysis of NEAU-wh3-1: An Embleya Strain with Antitumor and Antibacterial Activity
}

\author{
Han Wang ${ }^{1,+}$, Tianyu Sun ${ }^{1,+}{ }^{+}$Wenshuai Song ${ }^{1}$, Xiaowei Guo ${ }^{1}$, Peng Cao ${ }^{1}$, Xi Xu ${ }^{1}$, Yue Shen ${ }^{1,2, *}$ \\ and Junwei Zhao ${ }^{1, *(D)}$ \\ 1 Key Laboratory of Agricultural Microbiology of Heilongjiang Province, Northeast Agricultural University, \\ No. 600 Changjiang Road, Xiangfang District, Harbin 150030, China; \\ wanghan507555536@gmail.com (H.W.); sty1561214024@163.com (T.S.); wenshuaisong@163.com (W.S.); \\ guoweizi@hotmail.com (X.G.); cp511@126.com (P.C.); xuxi1758899581@126.com (X.X.) \\ 2 College of Science, Northeast Agricultural University, No. 600 Changjiang Road, Xiangfang District, \\ Harbin 150030, China \\ * Correspondence: shenyuelele@163.com (Y.S.); guyan2080@126.com (J.Z.) \\ + These authors contributed equally to this work.
}

Received: 28 February 2020; Accepted: 18 March 2020; Published: 20 March 2020

\begin{abstract}
Cancer is a serious threat to human health. With the increasing resistance to known drugs, it is still urgent to find new drugs or pro-drugs with anti-tumor effects. Natural products produced by microorganisms have played an important role in the history of drug discovery, particularly in the anticancer and anti-infective areas. The plant rhizosphere ecosystem is a rich resource for the discovery of actinomycetes with potential applications in pharmaceutical science, especially Streptomyces. We screened Streptomyces-like strains from the rhizosphere soil of wheat (Triticum aestivum L.) in Hebei province, China, and thirty-nine strains were obtained. Among them, the extracts of 14 isolates inhibited the growth of colon tumor cell line HCT-116. Strain NEAU-wh-3-1 exhibited better inhibitory activity, and its active ingredients were further studied. Then, 16S rRNA gene sequence similarity studies showed that strain NEAU-wh3-1 with high sequence similarities to Embleya scabrispora DSM $41855^{\mathrm{T}}(99.65 \%)$, Embleya hyalina MB891-A1 ${ }^{\mathrm{T}}(99.45 \%)$, and Streptomyces lasii $5 \mathrm{H}-\mathrm{CA} 11^{\mathrm{T}}(98.62 \%)$. Moreover, multilocus sequence analysis based on the five other house-keeping genes $(\operatorname{atp} \mathrm{D}, g y r \mathrm{~B}$, $r p o \mathrm{~B}, r e c \mathrm{~A}$, and $\operatorname{tr} p \mathrm{~B}$ ) and polyphasic taxonomic approach comprising chemotaxonomic, phylogenetic, morphological, and physiological characterization indicated that the isolate should be assigned to the genus Embleya and was different from its closely related strains, therefore, it is proposed that strain NEAU-wh3-1 may be classified as representatives of a novel species of the genus Embleya. Furthermore, active substances in the fermentation broth of strain NEAU-wh-3-1 were isolated by bioassay-guided analysis and identified by nuclear magnetic resonance (NMR) and mass spectrometry (MS) analyses. Consequently, one new Zincophorin analogue together with seven known compounds was detected. The new compound showed highest antitumor activity against three human cell lines with the $50 \%$ inhibition $\left(\mathrm{IC}_{50}\right)$ values of $8.8-11.6 \mu \mathrm{g} / \mathrm{mL}$ and good antibacterial activity against four pathogenic bacteria, the other known compounds also exhibit certain biological activity.
\end{abstract}

Keywords: Rhizosphere soil; Embleya; NEAU-wh-3-1; compound; antitumor activity; antibacterial activity

\section{Introduction}

Tumor, especially malignant tumor, has become one of the major diseases, which is a serious threat to the health of people around the world [1,2]. According to records of the World Health Organization 
(WHO) in 2018, more than 9 million people died of cancer, which was the second leading cause of death worldwide [3]. This figure will further rise because of aging, intensification of industrialization and urbanization, lifestyle modifications, etc. [2]. Thus, the burden of cancer cannot be ignored and the search for effective anticancer drugs is urgent [4]. On the other hand, the severe cancer incidence is also an invisible spur to the development of anti-tumor drugs throughout the world. So far, chemotherapy is still an important method for cancer treatment. Among the chemotherapeutics used, antitumor antibiotics derived from natural products account for a large proportion [5-7]. Natural product antibiotics were derived from various source materials including terrestrial plants, terrestrial microorganisms, marine organisms, and some invertebrates [8].

Microbial natural products have, in fact, been an excellent resource for drug discovery, particularly in the anticancer and anti-infective areas [9-11]. The phylum Actinobacteria accounts for a high proportion of soil microbial biomass and contains the most economically significant prokaryotes, producing more than half of the bioactive compounds in a literature survey, including antibiotics, antitumor agents, and enzymes [8,12-14]. Many famous antibiotics, such as bleomycin (BLM), mitomycin, anthracyclines [15], actinomycin D (ActD), polyether ionophore antibiotics, tetracyclines, quinolones, and so on, are derived from actinomycetes, which played an important role in the drug market [16]. Zincophorin, also referred to as M144255 or griseochellin, is a polyoxygenated ionophoric antibiotic [17], and has been reported to possess strong activity against Gram-positive bacteria and have strong cytotoxicity against human lung carcinoma cells A549 and Madin-Darby canine kidney cells MDCK $[17,18]$, which was also isolated from actinomycetes. As the main genus of Actinobacteria, Streptomyces is the largest antibiotic producer. More than $70 \%$ of nearly 10,000 microbial origin compounds are produced by Streptomyces while some rare actinobacterial genera only accounted for less than 30\% [19-22]. As abundant resources of larger number and wider variety of new antibiotics, Streptomyces strains have been continuously noted rather than any other actinomycete genera $[19,23]$. Streptomyces are widely distributed in terrestrial ecosystems, especially in the soil [24,25]. However, as time goes on, the possibility of finding novel compounds from Streptomyces in conventional soil has decreased and the rediscovery rate is high [22,26]. In recent years, studies on actinomycetes from diverse habitats have suggested new chemical structures and bioactive compounds [27,28]. Rhizosphere soil, the thin layer of soil around the roots of plants, has been a potential region for the discovery of functional microbes due to its special ecological environment. As early as the beginning of the last century, Hiltner proposed that there are more microorganisms in rhizosphere soil than surrounding soil [29-31]. There is a close relationship between rhizosphere microorganisms and plants. Plants can release organic compounds and signal molecules through root secretions to recruit microbial flora that are beneficial to their own growth. Microbes can control plant pathogens and pests by synthesizing multiple antibiotics, thereby indirectly promoting plant growth [32-34]. In recent years, many biologically active microorganisms and active substances produced by their secondary metabolism have been isolated from plant rhizosphere soil [35-38].

The genus Embleya, was very recently transferred from genus Streptomyces and established by Nouioui et al [39] and is a new member of the family Streptomycetaceae in the order Streptomycetales [39,40]. Embleya forms well-branched substrate mycelia with long aerial hyphae in open spirals and contains LL-diaminopimelic acid in the cell wall peptidoglycan, MK-9 $\left(\mathrm{H}_{4}\right)$ or $\mathrm{MK}-9\left(\mathrm{H}_{6}\right)$ as the major isoprenoid quinone and phosphatidylethanolamine (PE) as the predominant phospholipid [41], which is very similar to that of Streptomyces [42]. At present, the genus comprises only two species: Embleya scabrispora and Embleya hyaline. Embleya scabrispora was originally proposed as Streptomyces scabrisporus sp. nov. [43], and it has been reclassified to the genus Embleya as the type species [39,40], it could produce hitachimycin with antitumor, antibacterial, and antiprotozoal activities [44-46]; and Embleya hyaline was first described as Streptomyces hyalinum [41,47], and it has been reported to produce nybomycin which is an effective agent against antibiotic-resistant Staphylococcus aureus and it was called a reverse antibiotic [48]. 
In this study, an Embleya strain, NEAU-wh-3-1, with better antitumor activity was isolated from the wheat rhizosphere soil. The taxonomic identity of strain NEAU-wh3-1 was determined by a combination of $16 \mathrm{~S}$ rRNA gene sequence and five other house-keeping genes $(a t p \mathrm{D}, g y r \mathrm{~B}, r p o \mathrm{~B}, r e c \mathrm{~A}$, and $\operatorname{tr} \mathrm{B}$ ) analysis with morphological and physiological characteristics. The active substances of strain NEAU-wh-3-1 were also isolated, identified, and determined. Furthermore, the cytotoxicity and antimicrobial activity of the isolated compounds were tested.

\section{Materials and Methods}

\subsection{Isolation of Streptomyces-Like Strains}

Rhizosphere soil of wheat (Triticum aestivum L.) was collected from Langfang, Hebei Province, Central China $\left(39^{\circ} 32^{\prime} \mathrm{N}, 116^{\circ} 40^{\prime} \mathrm{E}\right)$. The soil sample should be protected from light and air-dried at room temperature for 14 days before isolation for Streptomyces-like strains. After drying, the soil sample was ground into powder and then suspended in sterile distilled water followed by a standard serial dilution technique. The diluted soil suspension was spread on humic acid-vitamin agar (HV) [49] supplemented with cycloheximide $\left(50 \mathrm{mg} \mathrm{L}^{-1}\right)$ and nalidixic acid $\left(20 \mathrm{mg} \mathrm{L}^{-1}\right)$. After 28 days of aerobic incubation at $28^{\circ} \mathrm{C}$, colonies were transferred and purified on the International Streptomyces Project (ISP) medium 3 [50], and maintained as glycerol suspensions $(20 \%, v / v)$ at $-80^{\circ} \mathrm{C}$ for long-period preservation.

\subsection{Screening of Strains with Antitumor Activity}

All the isolated were cultured on ISP medium 2 (yeast extract-malt extract agar) and incubated at $28{ }^{\circ} \mathrm{C}$ for 7 days. The spores of the strains were transferred into $250 \mathrm{~mL}$ Erlenmeyer flasks containing $30 \mathrm{~mL}$ of the production broth containing maltodextrin $4 \%$, lactose $4 \%$, yeast extract $0.5 \%$, and MOPS $2 \%$, at pH 7.2-7.4. on a rotary shaker at 250 r.p.m at $28{ }^{\circ} \mathrm{C}$. After seven days, the production broth was extracted with an equal volume of methanol for approximately $24 \mathrm{~h}$. After filtration, the filtrate substances were evaporated under reduced pressure at $50{ }^{\circ} \mathrm{C}$ to yield the crude extract and then dissolved in DMSO (dimethyl sulfoxide) at concentrations of $20 \mu \mathrm{g} / \mathrm{mL}$ and $100 \mu \mathrm{g} / \mathrm{mL}$. The HCT-116 (human colorectal carcinoma) cell lines were maintained in Dulbecco's modified Eagle's medium supplemented with $10 \%(w / v)$ fetal bovine serum in a humidified incubator at $37{ }^{\circ} \mathrm{C}$ of $5 \% \mathrm{CO}_{2}$ incubator. The antitumor activities of extracts with two concentrations were investigated by the SRB (Sulforhodamine B) colorimetric method. Briefly, treated cells were harvested and seeded at a density of $5 \times 10^{4}$ cells/well into a sterile flat bottom 96-well plate for $24 \mathrm{~h}$, the cells were treated with different concentrations of the extracts for $48 \mathrm{~h}$ and growth inhibition was measured by determining the optical density at $510 \mathrm{~nm}$, and the assay was performed basing on an established method [51].

\subsection{Morphological and Physiological and Biochemical Characteristics of NEAU-wh3-1}

Gram staining was carried out by using the standard method and morphological characteristics were observed by light microscopy (Nikon ECLIPSE E200, Nikon Corporation, Tokyo, Japan) and scanning electron microscopy (Hitachi SU8010, Hitachi Co., Tokyo, Japan) using cultures grown on ISP 3 agar at $28^{\circ} \mathrm{C}$ for 2 weeks. Samples for scanning electron microscopy were prepared as described by Jin et al. [52]. Growth at different temperatures $\left(4,10,15,20,25,28,32,37,40\right.$, and $\left.45^{\circ} \mathrm{C}\right)$ was determined on ISP 3 medium after incubation for 14 days. Growth tests for $\mathrm{pH}$ range ( $\mathrm{pH} 4.0-12.0$, at intervals of $1.0 \mathrm{pH}$ unit) using the buffer system described by Zhao et al. [53] and tolerance of various $\mathrm{NaCl}$ concentrations (0-10\%, with an interval of $1 \%$, $w / v)$ were tested in GY (Glucose-yeast extract powder) medium (glucose $1 \%$, yeast extract $1 \%, \mathrm{~K}_{2} \mathrm{HPO}_{4} 3 \mathrm{H}_{2} \mathrm{O} 0.05 \%, \mathrm{MgSO}_{4} 7 \mathrm{H}_{2} \mathrm{O} 0.05 \%, w / v, \mathrm{pH}$ 7.2) at $28^{\circ} \mathrm{C}$ for 14 days on a rotary shaker. Hydrolysis of Tweens (20,40, and 80) and production of urease were tested as described by Smibert and Krieg [54]. The utilization of sole carbon and nitrogen sources, decomposition of cellulose, hydrolysis of starch and aesculin, reduction of nitrate, coagulation 
and peptonization of milk, liquefaction of gelatin, and production of $\mathrm{H}_{2} \mathrm{~S}$ were examined as described previously $[55,56]$.

\subsection{Chemotaxonomic Analysis of NEAU-wh3-1}

Biomass for chemotaxonomic characterization was prepared by growing strain NEAU-wh3-1 in ISP 2 broth in shake flasks at $28{ }^{\circ} \mathrm{C}$ for 7 days. Cells were harvested by centrifugation, washed twice with distilled water, and freeze-dried. The whole-cell sugars were analyzed according to the procedures developed by Lechevalier and Lechevalier [57]. The polar lipids were examined by two-dimensional TLC (thin layer chromatography) and identified using the method of Minnikin et al. [58]. Menaquinones were extracted from freeze-dried biomass and purified according to Collins [59]. Streptomyces lutosisoli DSM $42165^{\mathrm{T}}$ [60] was used as the reference strain for identification of menaquinones. Extracts were analyzed by a HPLC-UV method [61] using an Agilent Extend-C18 Column $(150 \times 4.6 \mathrm{~mm}$, i.d. $5 \mu \mathrm{m})$ (Agilent Corp., Santa Clara, CA, USA) at $270 \mathrm{~nm}$.

\subsection{Phylogenetic Analysis of NEAU-wh3-1}

Extraction of genomic DNA, PCR amplification of the 16S rRNA gene sequence and sequencing of PCR products were carried out using a standard procedure [62]. The PCR product was purified and cloned into the vector pMD19-T (Takara Bio Inc., Dalian, China) and sequenced using an Applied Biosystems DNA sequencer (model 3730XL, Applied Biosystems Inc., Foster City, California, USA). The almost complete 16S rRNA gene sequence of strain NEAU-wh3-1, comprising $1487 \mathrm{bp}$, was obtained and compared with type strains available in the EzBioCloud server [63] and retrieved using NCBI BLAST (https://blast.ncbi.nlm.nih.gov/Blast.cgi;), and then submitted to the GenBank database. The phylogenetic tree was constructed based on the 16S rRNA gene sequences of strain NEAU-wh3-1 and related reference species. Sequences were multiply aligned in Molecular Evolutionary Genetics Analysis (MEGA) using the Clustal W algorithm and trimmed manually where necessary. Phylogenetic trees were generated with the neighbor-joining [64] and maximum-likelihood [65] algorithms using MEGA software version MEGA 7.0 [66]. The stability of the topology of the phylogenetic tree was assessed using the bootstrap method with 1000 replicates [67]. A distance matrix was generated using Kimura's two-parameter model [68]. All positions containing gaps and missing data were eliminated from the dataset (complete deletion option). The gyrB gene was amplified with primers PF-1 and PR-2 [69] under the PCR program for $16 \mathrm{~S} r R N A$ gene. PCR of the $\operatorname{at} p \mathrm{D}, \operatorname{rec} \mathrm{A}, r p o \mathrm{~B}$, and $\operatorname{tr} p \mathrm{~B}$ genes were performed using primers and amplification conditions described by Guo et al. [70]. The sequence data were exported as single gene alignments or a concatenated five-gene alignment for subsequent analysis as described above. Trimmed sequences of the five housekeeping genes were concatenated head-to-tail in-frame in the order $a t p \mathrm{D}$ (430 bp)-gyrB (354 bp)-recA (431 bp)-rpoB (208 bp)-trpB (556 bp). Phylogenetic analysis was performed as described above.

\subsection{Production}

The strain Embleya sp. NEAU-wh3-1 was grown on the ISP medium 2 (yeast extract-malt extract agar) and incubated for $6-7$ days at $28^{\circ} \mathrm{C}$. The spores of the strain were transferred into two $1.0 \mathrm{~L}$ Erlenmeyer flasks containing $250 \mathrm{~mL}$ of the seed medium and incubated at $28^{\circ} \mathrm{C}$ for $48 \mathrm{~h}$ on a rotary shaker at 250 r.p.m. All of the media were sterilized at $121^{\circ} \mathrm{C}$ for $30 \mathrm{~min}$. The seed culture ( $8 \%$ ) was transferred into 60 flasks $(1.0 \mathrm{~L})$ containing $250 \mathrm{~mL}$ of production broth. The production broth was composed of maltodextrin $4 \%$, lactose $4 \%$, yeast extract $0.5 \%$, MOPS $2 \%$, at pH $7.2-7.4$. The flasks were incubated at $28^{\circ} \mathrm{C}$ for 7 days, shaken at 250 r.p.m.

\subsection{Extraction and Isolation}

The final 15.0 L production broth was filtered to separate supernatant and mycelial cake. The supernatant was subjected to a Diaion HP-20 resin column and eluted with 95\% EtOH. The mycelial cake was washed with water (3 L) and subsequently extracted with $\mathrm{MeOH}$ (3 L) to obtain soluble 
material. The $\mathrm{MeOH}$ extract and the $\mathrm{EtOH}$ eluents were evaporated under reduced pressure at $50{ }^{\circ} \mathrm{C}$ to yield the crude extract ( $24 \mathrm{~g}$ ). The crude extract was chromatographed on a silica gel column and eluted with a stepwise gradient of $\mathrm{CH}_{2} \mathrm{Cl}_{2} / \mathrm{MeOH}$ (95:5/90:10/85:15/80:20/70:30/65:35, v/v) and giving three fractions (Fr.1-Fr.3) based on the TLC profiles, which was performed on silica-gel plates with solvent system of $\mathrm{CHCl}_{3} / \mathrm{MeOH}(9: 1, v / v)$. The Fr.1 was subjected to a Sephadex LH-20 column eluted with $\mathrm{CH}_{2} \mathrm{Cl}_{2} / \mathrm{MeOH}(1: 1, v / v)$ and detected by TLC to give two subfractions (Fr.1-1-Fr.1-2). The Fr.1-1 was further isolated by semi-preparative HPLC (Agilent 1100, Zorbax SB-C18, $5 \mu \mathrm{m}, 250 \times 9.4 \mathrm{~mm}$ inner diameter; $1.5 \mathrm{~mL} \mathrm{~min}{ }^{-1} ; 254 \mathrm{~nm}$; Agilent, PaloAlto, CA, USA) eluting with $\mathrm{CH}_{3} \mathrm{CN} / \mathrm{H}_{2} \mathrm{O}(90: 10$, $v / v)$ to give compound $1\left(t_{R} 25.06 \mathrm{~min}, 10.5 \mathrm{mg}\right)$, the Fr.1-2 was further isolated by preparative HPLC (Shimadzu LC-8 A, Shimadzu-C18, $5 \mu \mathrm{m}, 250 \times 20 \mathrm{~mm}$ inner diameter; $20 \mathrm{~mL} \mathrm{~min}{ }^{-1} ; 220 / 254 \mathrm{~nm}$; Shimadzu, Kyoto, Japan) eluting with a stepwise gradient $\mathrm{MeOH} / \mathrm{H}_{2} \mathrm{O}(30-80 \%, v / v 30 \mathrm{~min})$, and giving compound $2\left(t_{R} 12.7 \mathrm{~min}, 7.5 \mathrm{mg}\right)$, compound $3\left(t_{R} 17.5 \mathrm{~min}, 12.7 \mathrm{mg}\right)$ and compound $4\left(t_{R} 22.6 \mathrm{~min}\right.$, $16.3 \mathrm{mg})$. The Fr.2 was subjected to another silica gel column eluted with n-hexane/acetone (95:5-60:40, $v / v$ ) and further purified by semi-preparative HPLC (Agilent 1100, Zorbax SB-C18, $5 \mu \mathrm{m}, 250 \times 9.4$ mm inner diameter; $1.5 \mathrm{mLmin}^{-1} ; 254 \mathrm{~nm}$; Agilent, PaloAlto, CA, USA) eluting with $\mathrm{CH}_{3} \mathrm{CN} / \mathrm{H}_{2} \mathrm{O}$ $(75: 25, v / v)$ to give compound $5\left(t_{R} 15.1 \mathrm{~min}, 13.5 \mathrm{mg}\right)$ and compound $6\left(t_{R} 24.3 \mathrm{~min}, 18.5 \mathrm{mg}\right)$. Fr.3 was treated by an another silica gel column and eluted with a stepwise gradient of $n$-hexane/acetone (100:0-40:60, v/v) to give three fractions Fr.3-1-Fr.3-3 according to their TLC profiles, which was observed on silica-gel plates with solvent system of $n$-hexane/acetone $(1: 3, v / v)$. The Fr.3-3 was further purified by semi-preparative HPLC (Agilent 1260, Zorbax SB-C18, $5 \mu \mathrm{m}, 250 \times 9.4 \mathrm{~mm}$ inner diameter; $1.5 \mathrm{~mL}$ $\mathrm{min}^{-1}$; 220nm; $254 \mathrm{~nm}$; Agilent, PaloAlto, CA, USA) eluting with $\mathrm{CH}_{3} \mathrm{CN} / \mathrm{H}_{2} \mathrm{O}(45: 55, v / v)$ to obtain compounds $7\left(t_{R} 25.1 \mathrm{~min}, 13.0 \mathrm{mg}\right)$ and $8\left(t_{\mathrm{R}} 30.1 \mathrm{~min}, 7.5 \mathrm{mg}\right)$.

\subsection{General Experimental Procedures}

IR spectra were recorded on a Thermo Nicolet Avatar FT-IR-750 spectrophotometer (Thermo, Tokyo, Japan) using KBr disks. Optical rotations were measured on a Perkin-Elmer 341 polarimeter (PerkinElmer, Inc. Suzhou, China). UV spectra were recorded on a Varian CARY 300 BIO spectrophotometer (Varian, Cary, NC, USA). The HR-ESI-MS and ESI-MS were taken on a Q-TOF Micro LC-MS-MS mass spectrometer (Waters Co, Milford, MA, U.S.A.). Nuclear magnetic resonance (NMR) spectra (400 MHz for ${ }^{1} \mathrm{H}$ and $100 \mathrm{MHz}$ for ${ }^{13} \mathrm{C}$ ) were measured with a Bruker DRX-400 spectrometer (Bruker, Rheinstetten, Germany). HPLC analysis was performed on a preparative HPLC (Shimadzu

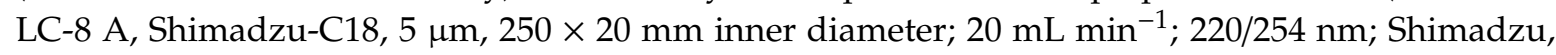
Kyoto, Japan) as well as a semipreparative HPLC (Agilent 1100, Zorbax SB-C18, $5 \mu \mathrm{m}, 250 \times 9.4 \mathrm{~mm}$ inner diameter; $1.5 \mathrm{~mL} / \mathrm{min} ; 220 / 254$ nm; Agilent, Palo Alto, CA, USA). Column chromatography were consisted of silica gel (100-200 mesh, Qingdao Haiyang Chemical Group Co., Qingdao, China) as well as Sephadex LH-20 gel (GE Healthcare, Glies, UK), which were analyzed by thin-layer chromatography (TLC). TLC was performed on silica-gel plates (HSGF254, Yantai Chemical Industry Research Institute, Yantai, China) and the developed plates were observed under a UV lamp at $254 \mathrm{~nm}$ or by heating after spraying with sulfuric acid-ethanol, 5:95 (v/v).

\subsection{Biological Assays}

The cytotoxicity of the eight compounds was assayed by cell counting kit-8 (CCK-8) colorimetric method [71] in vitro against the human leukemia cells K562, hepatocellular liver carcinoma cell line HepG2, and the human colon tumor cell line HCT-116. The cell lines were routinely in Dulbecco's Modified Eagle's Medium (DMEM) containing $10 \%$ calf serum at $37{ }^{\circ} \mathrm{C}$ for $4 \mathrm{~h}$ in a humidified atmosphere of $5 \% \mathrm{CO}_{2}$ incubator. The adherent cells at logarithmic phase were digested by pancreatic enzymes and inoculated onto 96-well culture plate at a density of $1.0 \times 10^{4}$ cells per/well. Test samples and control were dissolved in DMSO (dimethyl sulfoxide) and then added to the medium, incubated for $72 \mathrm{~h}$. Then, the cell counting kit-8 (CCK-8, Dojindo, Kumamoto, Japan) reagent was added to the medium followed by further incubation for $3 \mathrm{~h}$. Absorbance at $450 \mathrm{~nm}$ with a $600 \mathrm{~nm}$ reference was 
measured thereafter using a SpectraMax M5 microplate reader (Molecular Devices Inc., Sunnyvale, CA, USA). The inhibitory rate of cell proliferation was expressed as $\mathrm{IC}_{50}$ values and calculated by the following formula:

$$
\text { Growth inhibition }(\%)=[\text { ODcontrol-ODtreated }] / \text { ODcontrol } \times 100
$$

Doxorubicin was tested as a positive control, and cell solutions containing $0.5 \%$ DMSO were tested as a negative control.

The antibacterial activities of the isolated compounds were tested against Gram-positive bacteria Staphylococcus aureus, Bacillus subtilis, and Sarcina lutea and Gram-negative bacteria Klebsiella pneumoniae and Escherichia coli with the minimum inhibitory concentration (MIC) method recommended by the Clinical and Laboratory Standards Institute [72].

\section{Results}

\subsection{Isolation and Screening of an Antitumor Compound Producing Strains}

Thirty-nine strains belonging to actinomycetes were isolated from the soil samples. The crude extracts of these isolates were examined for their cytotoxic activity at dilution concentrations of 100 $\mu \mathrm{g} / \mathrm{mL}$ and $20 \mu \mathrm{g} / \mathrm{mL}$. As a result of primary screening, fourteen strains showed cytotoxic activity to human colon tumor cell line HCT-116 (Figure 1). Due to the superior cytotoxic activity of strain NEAU-wh3-1, which inhibition rate was greater than $80 \%$ at both concentrations, further chemical investigations were performed on this strain.

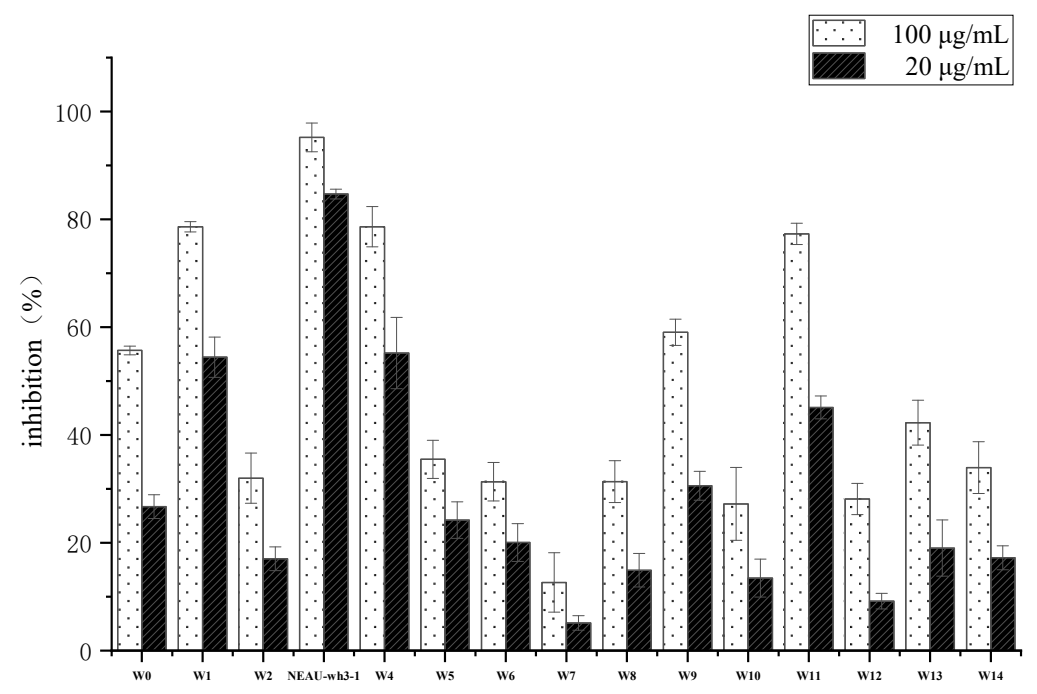

Figure 1. Antitumor activities of extracts obtained from fourteen isolates against human colon tumor cell line HCT-116.

\subsection{Polyphasic Taxonomic Characterization of NEAU-wh3-1}

Morphological observation of 2-week-old cultures of strain NEAU-wh3-1 grown on ISP 3 medium revealed that the strain has the typical characteristics of genus Embleya and formed well-developed, branched substrate hyphae and aerial mycelium that differentiated into spiral spore chains consisted of cylindrical spores $(0.6-0.8 \mu \mathrm{m} \times 0.9-1.3 \mu \mathrm{m})$, the spores were rough-surfaced and non-motile (Figure 2$)$. Strain NEAU-wh3-1 was found to grow at a temperature range of 4 to $37^{\circ} \mathrm{C}$ (optimum temperature $28{ }^{\circ} \mathrm{C}$ ), $\mathrm{pH} 5$ to 12 (optimum $\mathrm{pH} 7$ ), and $\mathrm{NaCl}$ tolerance of $0 \%$ to $3 \%$ (optimum $\mathrm{NaCl}$ of $1 \%$ ). The physiological and biochemical properties of strain NEAU-wh3-1, Embleya scabrispora DSM 41855 ${ }^{\mathrm{T}}$, Embleya hyalina MB891-A1 ${ }^{\mathrm{T}}$, and Streptomyces lasii $5 \mathrm{H}-\mathrm{CA} 11^{\mathrm{T}}$ are given in Table 1. 


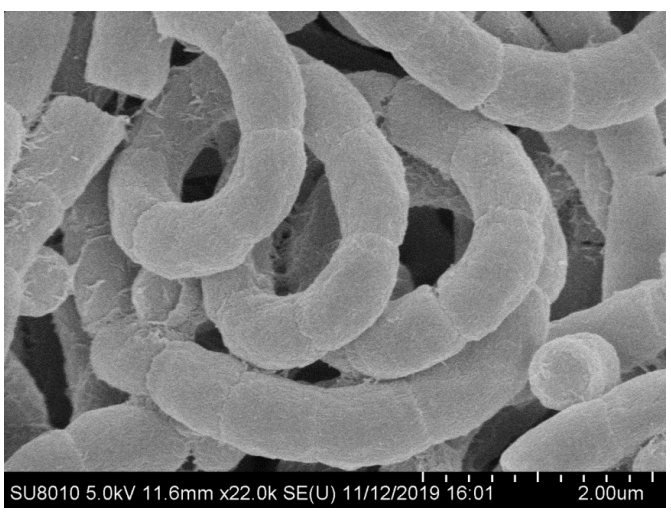

Figure 2. Scanning electron micrograph of spore chains of strain NEAU-wh3-1 grown on ISP 3 agar for 2 weeks at $28^{\circ} \mathrm{C}$.

Table 1. The physiological and biochemical properties of strain NEAU-wh3-1, Embleya scabrispora DSM $41855^{\mathrm{T}}$, Embleya hyalina MB891-A1 ${ }^{\mathrm{T}}$, Streptomyces lasii $5 \mathrm{H}^{-\mathrm{CA} 11^{\mathrm{T}}}$.

\begin{tabular}{|c|c|c|c|c|}
\hline Characteristic & 1 & $2^{a, c}$ & $3^{b}$ & $4^{c}$ \\
\hline \multicolumn{5}{|l|}{ Decomposition of } \\
\hline Cellulose & - & - & ND & + \\
\hline Tween 20 & - & + & ND & + \\
\hline Tween 40 & + & + & ND & + \\
\hline Tween 80 & - & + & ND & + \\
\hline Liquefaction of gelatin & - & - & + & + \\
\hline Growth temperature $\left({ }^{\circ} \mathrm{C}\right)$ & $4-37$ & $18-36$ & $10-28$ & $15-38$ \\
\hline $\mathrm{pH}$ range for growth & $5-12$ & $4-10$ & $6-11$ & $5-11$ \\
\hline $\mathrm{NaCl}$ tolerance range $(w / v, \%)$ & $0-3$ & $0-3$ & $0-1$ & $0-2.5$ \\
\hline Milk coagulation & - & $\mathrm{w}$ & - & + \\
\hline Nitrate reduction & - & + & - & - \\
\hline Starch hydrolysis & - & $\mathrm{w}$ & - & - \\
\hline \multicolumn{5}{|l|}{ Carbon source utilization } \\
\hline $\mathrm{L}$-arabinose & + & \pm & - & - \\
\hline Dulcitol & + & $\mathrm{w}$ & - & $\mathrm{W}$ \\
\hline D-Fructose & + & - & + & - \\
\hline D-Galactose & + & - & + & - \\
\hline D-Glucose & + & + & + & + \\
\hline Inositol & - & + & + & - \\
\hline Lactose & + & + & - & + \\
\hline D-Maltose & + & - & \pm & - \\
\hline D-Mannitol & + & - & - & - \\
\hline D-Mannose & + & - & + & - \\
\hline D-Raffinose & + & - & - & + \\
\hline D-Ribose & - & + & ND & - \\
\hline D-Sorbitol & + & - & - & - \\
\hline D-Sucrose & + & \pm & W & + \\
\hline D-Xylose & + & + & - & - \\
\hline L-Rhamnose & - & + & + & - \\
\hline \multicolumn{5}{|l|}{ Nitrogen source utilization } \\
\hline L-Alanine & + & $\mathrm{W}$ & ND & + \\
\hline L-Arginine & + & $\mathrm{W}$ & ND & + \\
\hline L-Asparagine & + & $\mathrm{W}$ & ND & - \\
\hline L-Aspartic acid & + & + & ND & + \\
\hline Creatine & + & $\mathrm{w}$ & ND & - \\
\hline L-Glutamic acid & + & $\mathrm{w}$ & ND & + \\
\hline L-Glutamine & + & $\mathrm{w}$ & ND & + \\
\hline Glycine & + & $\mathrm{w}$ & ND & + \\
\hline L-Proline & - & + & ND & + \\
\hline L-Serine & + & - & ND & - \\
\hline L-Threonine & + & $\mathrm{w}$ & ND & + \\
\hline L-Tyrosine & + & + & ND & + \\
\hline Phospholipids & $\begin{array}{l}\text { DPG, PE, } \\
\text { PI, UL }\end{array}$ & PE, PGL & DPG, PE, PI & $\begin{array}{l}\text { DPG, PME, } \\
\text { PI, PIM, GL }\end{array}$ \\
\hline \multirow{3}{*}{ Menaquinones } & MK-9 $\left(\mathrm{H}_{4}\right)$, & MK-9 $\left(\mathrm{H}_{2}\right)$, & MK-9 $\left(\mathrm{H}_{4}\right)$, & MK-9( $\left.\mathrm{H}_{4}\right)$, \\
\hline & MK-9( $\left.\mathrm{H}_{6}\right)$, & MK-9 $\left(\mathrm{H}_{4}\right)$, & MK-9( $\left.\mathrm{H}_{6}\right)$, & MK-9( $\left.\mathrm{H}_{6}\right)$, \\
\hline & MK-9(H8) & MK-9 $\left(\mathrm{H}_{6}\right)$ & MK-9(H $\left.\mathrm{H}_{8}\right)$ & MK-9 $\left(\mathrm{H}_{8}\right)$ \\
\hline Whole cell-wall sugars & Arabinose, glucose, ribose & Arabinose & Arabinose, glucose & Glucose, ribose \\
\hline
\end{tabular}

Strains: 1, NEAU-wh3-1; 2, Embleya scabrispora DSM 41855 ${ }^{\mathrm{T}}$; 3, Embleya hyalina MB891-A1 ${ }^{\mathrm{T}}$; 4, Streptomyces lasii $5 \mathrm{H}-\mathrm{CA} 11^{\mathrm{T}}$. Abbreviation: + , positive; -, negative; \pm , ambiguous; ND, not determined; $\mathrm{w}$, weak; DPG, diphosphatidylglycerol; PME, phosphatidylmonomethylethanolamine; PE, phosphatidylethanolamine; PI, phosphatidylinositol; PIM, phosphatidylinositolmannoside; UL, unidentified lipid; GL, glucosamine-containing lipid; PGL, phospholipid containing glucosamine. All data are from this study except where marked. ${ }^{a}$ Data from Ping et al. [43]; ${ }^{\mathrm{b}}$ Data from Komaki et al. [41]; ${ }^{\mathrm{c}}$ Data from Liu et al. [73]. 
Chemotaxonomic analyses revealed that strain NEAU-wh3-1 contained LL-diaminopimelic acid as cell wall diamino acid. The whole-cell sugar was found to contain arabinose, glucose, and ribose. The phospholipid profile consisted of diphosphatidylglycerol (DPG), phosphatidylethanolamine (PE), phosphatidylinositol (PI), and two unidentified lipids (ULs) (Supplementary Figure S1). The menaquinones detected were MK-9 $\left(\mathrm{H}_{4}\right)(46.5 \%)$, MK-9 $\left(\mathrm{H}_{6}\right)(45.8 \%)$, and MK-9 $\left(\mathrm{H}_{8}\right)(7.7 \%)$.

The almost complete 16S rRNA gene sequence of strain NEAU-wh3-1 (1487 bp) was determined and deposited with the accession number MN928616 in the GenBank/EMBL (European Molecular Biology Laboratory)/DDBJ (DNA Data Bank of Japan) databases. EzBioCloud analysis suggests that strain NEAU-wh3-1 shared the highest 16S rRNA gene sequence similarities with Embleya scabrispora DSM 41855 ${ }^{\mathrm{T}}$ (99.65\%), Embleya hyalina MB891-A1 ${ }^{\mathrm{T}}(99.45 \%)$, and Streptomyces lasii $5 \mathrm{H}-\mathrm{CA} 11^{\mathrm{T}}$ (98.62\%). Phylogenetic analysis based on the 16S rRNA gene sequences indicated that the strain formed a stable cluster with E. scabrispora DSM 41855 ${ }^{\mathrm{T}}$, E. hyalina MB891-A1 ${ }^{\mathrm{T}}$, and S. lasii 5H-CA11 ${ }^{\mathrm{T}}$ based on neighbor-joining algorithm (Figure 3) and also supported by the maximum-likelihood algorithm (Supplementary Figure S2). To further clarify the affiliation of strain NEAU-wh3-1 to its closely related strains, partial sequences of housekeeping genes including atp $\mathrm{D}, g y r \mathrm{~B}, \operatorname{rec} \mathrm{A}, r p o \mathrm{~B}$, and $t_{r p} \mathrm{~B}$ were obtained. GenBank accession numbers of the sequences are displayed in Table S1. The phylogenetic tree based on the neighbor-joining tree constructed from the concatenated sequence alignment (1979 bp) of five housekeeping genes (Figure 4) suggested that the isolate clustered with $E$. scabrispora DSM $41855^{\mathrm{T}}$ and E. hyalina MB891-A1 ${ }^{\mathrm{T}}$, and also supported by the maximum-likelihood algorithm (Streptomyces lasii $5 \mathrm{H}-\mathrm{CA} 11^{\mathrm{T}}$ lacks housekeeping genes; Supplementary Figure S3). Moreover, pairwise distances calculated for NEAU-wh3-1 and the related species using concatenated sequences of atpD-gyrB-recA-rpoB-trpB were well above 0.007 (Table S2) for the related species, which was considered to be the threshold for species determination [74].

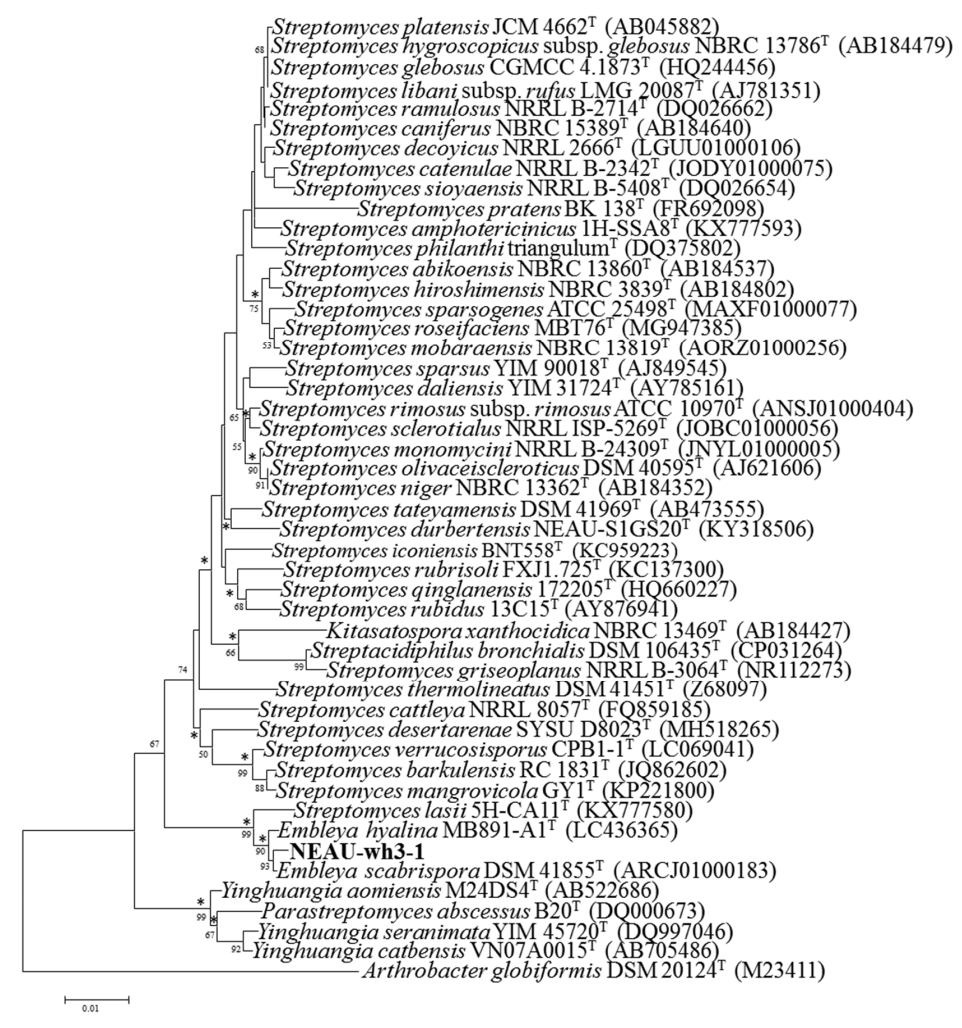

Figure 3. Neighbor-joining tree showing the phylogenetic position of strain NEAU-wh3-1 (1487 bp) and related taxa based on 16S rRNA gene sequences. Bootstrap values $>50 \%$ (based on 1000 replications) are shown at branch points. Arthrobacter globiformis DSM $20124^{\mathrm{T}}$ (M23411) was used as an outgroup. Asterisks indicate branches also recovered in the maximum-likelihood tree; Bar, 0.01 substitutions per nucleotide position. 


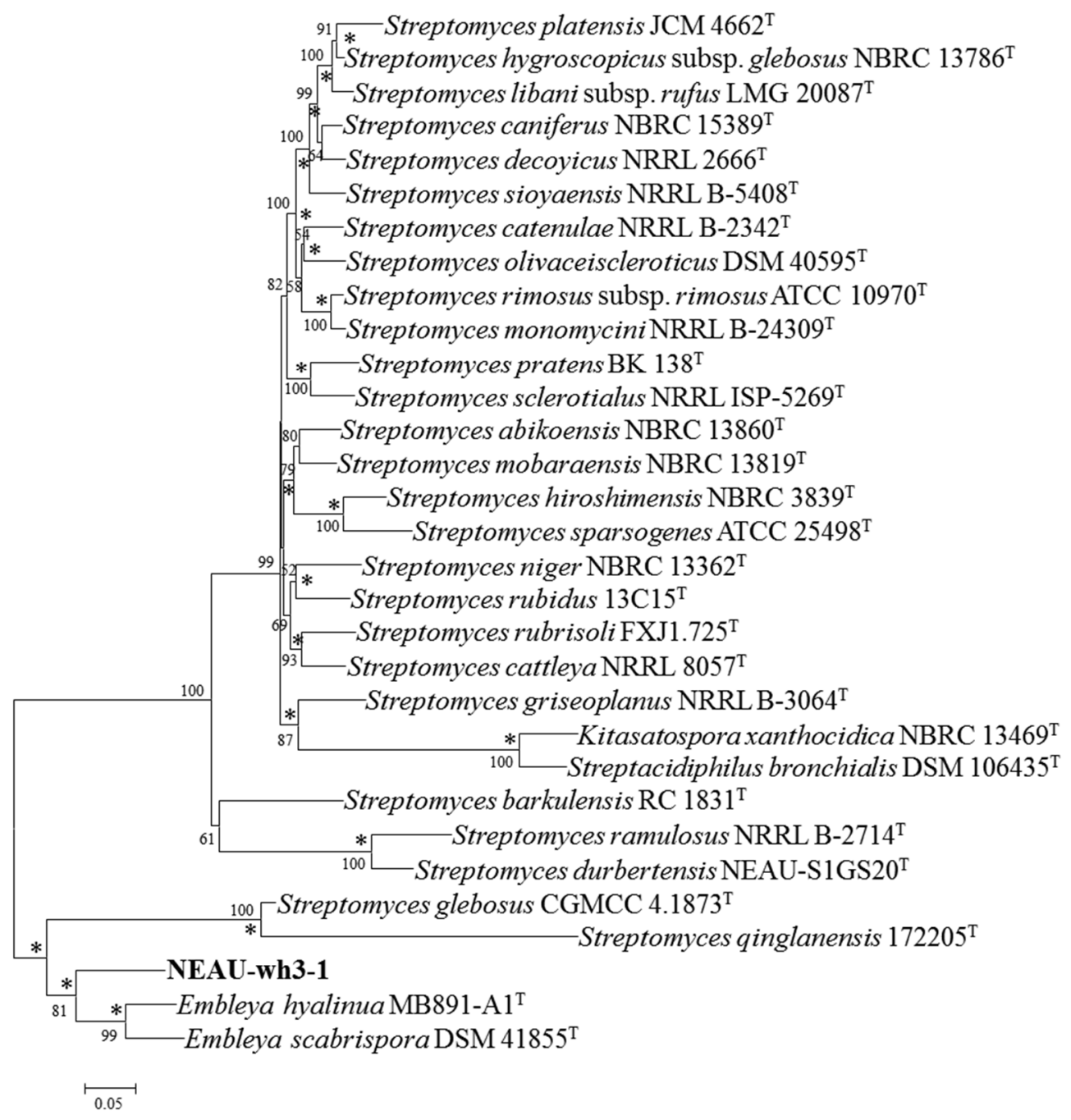

Figure 4. Neighbor-joining tree based on multilocus sequence analysis (MLSA) analysis of the concatenated partial sequences ( $1979 \mathrm{bp}$ ) from five housekeeping genes ( $\operatorname{tat} \mathrm{D}, g y r \mathrm{~B}, \operatorname{rec} \mathrm{A}, \operatorname{rpo} \mathrm{B}$, and $\operatorname{tr} p \mathrm{~B})$ of strain NEAU-wh3-1 (in bold) with related taxa. Only bootstrap values above $50 \%$ (percentages of 1000 replications) are indicated. Asterisks indicate branches also recovered in the maximum-likelihood tree; Bar, 0.05 substitutions per nucleotide position.

\subsection{Structural Elucidation}

The strain NEAU-wh3-1 was grown preparative scale in $15.0 \mathrm{~L}$ of production broth for 7 days. Bioassay-guided isolation of the active components of the strain yielded eight main bioactive compounds. Compounds 2-8 are known compounds, which structures were elucidated as conglobatin (2) [75], piericidin C1 (3) [76], piericidin C5 (4) [77], piericidin A1 (5) [78], piericidin A3 (6) [76], Mer-A 2026 A (7) [79], and BE-52211 D (8) [80] by analysis of their spectroscopic data and comparison with literature values (Figure 5, Figures S12-S27). Compound 1 is a new zincophorin analogue (Figure 6, Figures S4-S11) [17]. 


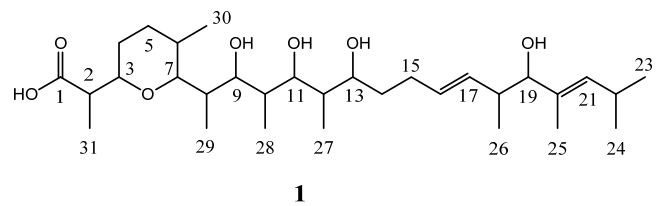<smiles>CCCCCCCCCCCCC=C(C)CCc1nc(OC)c(OC)c(O)c1C</smiles><smiles>CC[C@@H]1O[C@]1(C)[C@@H](O)[C@@H](C)/C=C(C)/C=C/C/C(C)=C/Cc1nc(OC)c(OC)c(O)c1C</smiles><smiles>CC(=C[C@@H](C)Cc1cnco1)C(=O)O[C@H](Cc1cnco1)[C@H](C)C[C@H](C)C=C(C)[C@H](C)CC(C)C</smiles>

conglobatin (2)

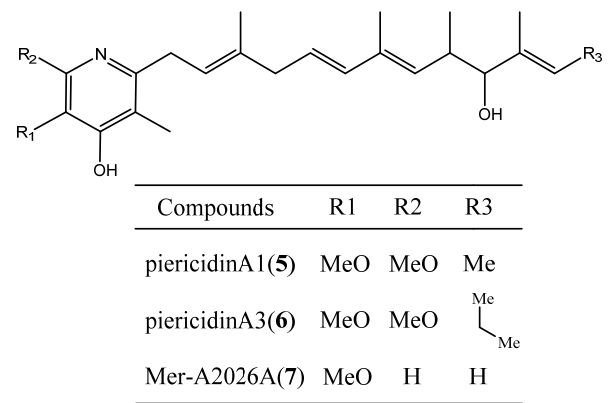<smiles>CC(=O)NC[C@H](O)CCC/C=C(C)/C=C(/C)c1ccc(C)cc1/C=C/CO</smiles>

BE-52211 D (8)

Figure 5. The structures of compounds 1-8. Compound $\mathbf{1}$ was isolated as white solid with $[\alpha]_{D}^{25}+15$ (c 0.043, EtOH) and UV (EtOH) $\lambda$ max nm $(\log \varepsilon): 202$ (4.53). Its molecular formula was established as $\mathrm{C}_{31} \mathrm{H}_{56} \mathrm{O}_{7}$ by HR-ESI-MS at $m / z 539.3942$ [M-H] $]^{-}$(calcd 539.3953 as $\mathrm{C}_{31} \mathrm{H}_{55} \mathrm{O}_{7}$ ). The IR spectrum revealed hydroxyl absorption at $3320 \mathrm{~cm}^{-1}$ and carbonyl absorption at $1735 \mathrm{~cm}^{-1}$, as well as methyl and methylene absorptions at $2953 \mathrm{~cm}^{-1}$ and $2924 \mathrm{~cm}^{-1}$.
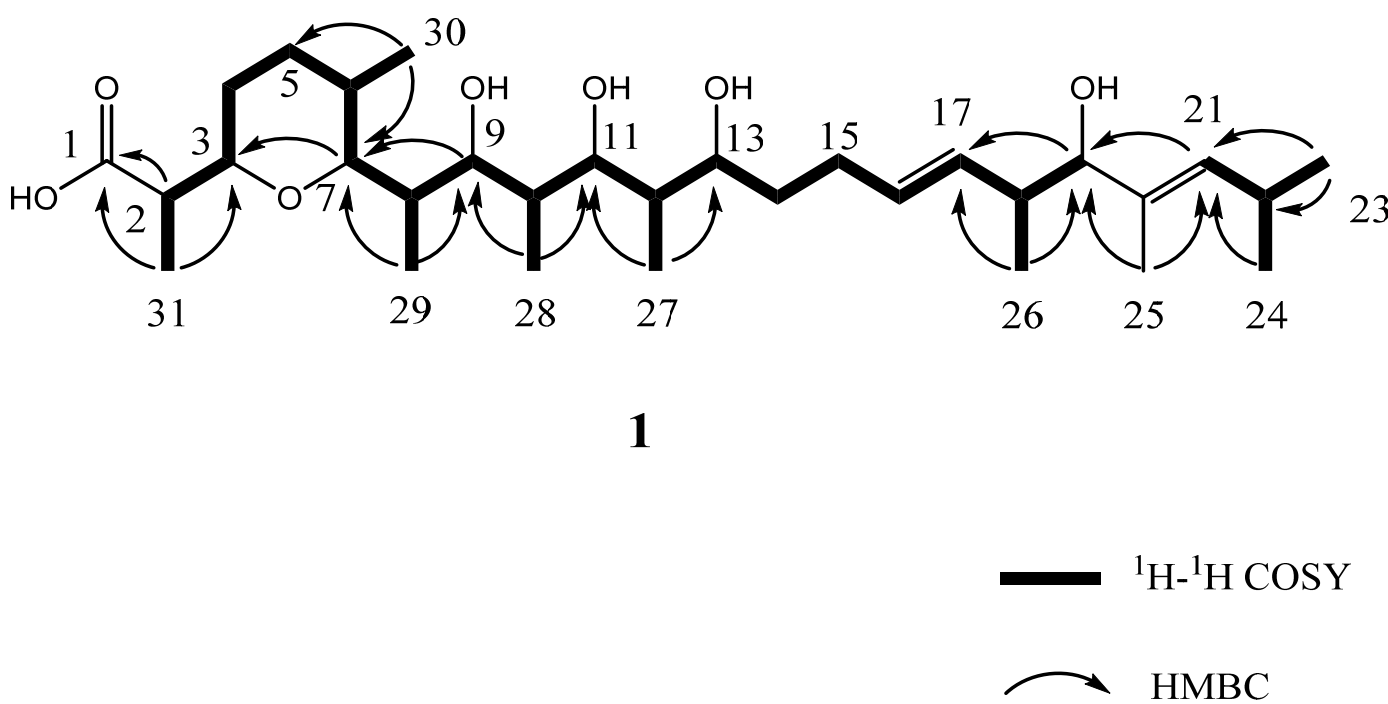

Figure 6. 2D nuclear magnetic resonance (NMR) correlations of compound $\mathbf{1 .}$

Analysis of ${ }^{1} \mathrm{H}$ NMR spectrum of 1 revealed the presence of three olefinic protons at $\delta_{\mathrm{H}} 5.52(1 \mathrm{H}$, $\mathrm{m}), 5.36(1 \mathrm{H}, \mathrm{m}), 5.20(1 \mathrm{H}, \mathrm{d}, J=8.9 \mathrm{~Hz})$, seven aliphatic methine protons at $\delta_{\mathrm{H}} 4.07(1 \mathrm{H}, \mathrm{m}), 4.06(1 \mathrm{H}$, m), $3.77(1 \mathrm{H}, \mathrm{d}, J=8.9 \mathrm{~Hz}), 3.72(1 \mathrm{H}, \mathrm{dd}, J=9.6,2.1 \mathrm{~Hz}), 3.58(1 \mathrm{H}, \mathrm{d}, J=9.2 \mathrm{~Hz}), 3.49(1 \mathrm{H}, \mathrm{m}), 3.28(1 \mathrm{H}$, $\mathrm{m})$, seven methylene protons at $\delta_{\mathrm{H}} 2.18(1 \mathrm{H}, \mathrm{m}), 2.13(1 \mathrm{H}, \mathrm{m}), 1.77(1 \mathrm{H}, \mathrm{m}), 1.67(2 \mathrm{H}, \mathrm{m}), 1.40(1 \mathrm{H}, \mathrm{m})$, 
$1.35(1 \mathrm{H}, \mathrm{m}), 1.28(1 \mathrm{H}, \mathrm{m})$, one singlet methyl at $\delta_{\mathrm{H}} 1.63 \mathrm{~s}$, in addition to eight doublet methyl protons at $\delta_{\mathrm{H}} 1.18(3 \mathrm{H}, \mathrm{d}, J=7.1 \mathrm{~Hz}), 1.15(3 \mathrm{H}, \mathrm{d}, J=7.2 \mathrm{~Hz}), 1.11(3 \mathrm{H}, \mathrm{d}, J=7.0 \mathrm{~Hz}), 0.98(3 \mathrm{H}, \mathrm{d}, J=6.5 \mathrm{~Hz}), 0.97$ $(3 \mathrm{H}, \mathrm{d}, J=6.6 \mathrm{~Hz}), 0.86(3 \mathrm{H}, \mathrm{d}, J=6.7 \mathrm{~Hz}), 0.81(3 \mathrm{H}, \mathrm{d}, J=6.5 \mathrm{~Hz}), 0.70(3 \mathrm{H}, \mathrm{d}, J=6.7 \mathrm{~Hz})$. The ${ }^{13} \mathrm{C} \mathrm{NMR}$ and DEPT135 spectra (Table 2) of 1 showed 31 resonances attributable to a carbonyl carbon at $\delta_{\mathrm{C}} 175.6$, one $s p^{2}$ quaternary carbon at $\delta_{C} 132.3$, three $s p^{2}$ methines at $\delta_{C} 136.6,134.5,132.4$. In the $s p^{3}$-carbon region, the spectrum showed six oxygenated methines at $\delta_{C} 84.3,83.3,81.7,76.1,74.0,69.4$, six methines at $\delta_{C} 42.2,37.1,36.5,36.0,33.0,26.1$, four methylenes at $\delta_{C} 34.2,28.6,27.1,24.9$ and nine methyl carbons at $\delta_{\mathrm{C}} 22.9,22.9,17.1,16.7,15.4,12.3,11.3,10.8,10.1$. The ${ }^{1} \mathrm{H}-{ }^{1} \mathrm{H}$ COSY correlations (Figure 6) of $\quad \mathrm{H}-2 / \mathrm{H}-3 / \mathrm{H}_{2}-4 / \mathrm{H}_{2}-5 / \mathrm{H}-6 / \mathrm{H}-7 / \mathrm{H}-8 / \mathrm{H}-9 / \mathrm{H}-10 / \mathrm{H}-11 / \mathrm{H}-12 / \mathrm{H}-13 / \mathrm{H}_{2}-14 / \mathrm{H}_{2}-15 / \mathrm{H}-16 / \mathrm{H}-17 / \mathrm{H}-18 / \mathrm{H}-19$ established connectivity from $\mathrm{H}-2$ atom along the chain through to $\mathrm{C}-19$ atom. The correlations between $\mathrm{H}-21 / \mathrm{H}-22 / \mathrm{H}_{3}-23 / \mathrm{H}_{3}-24, \mathrm{H}-12 / \mathrm{H}_{3}-27, \mathrm{H}-10 / \mathrm{H}_{3}-28, \mathrm{H}-18 / \mathrm{H}_{3}-26, \mathrm{H}-8 / \mathrm{H}_{3}-29$ protons in the ${ }^{1} \mathrm{H}-{ }^{1} \mathrm{H}$ COSY spectrum (Figure 6) indicated the five structural units of C-21-C-24, C-18-C-26, C-12-C-27, C-10-C-28, C-8-C-29. The observed HMBC (heteronuclear multiple bond correlation) correlations (Figure 6) from $\mathrm{H}_{3}-23, \mathrm{H}_{3}-24$ to C-21, C-22, from $\mathrm{H}_{3}-25$ to C-19, C-21, from $\mathrm{H}_{3}-26$ to C-17, C-18, and C-19, from $\mathrm{H}_{3}-27$ to $\mathrm{C}-11, \mathrm{C}-12$, and $\mathrm{C}-13$, from $\mathrm{H}_{3}-28$ to $\mathrm{C}-9, \mathrm{C}-10, \mathrm{C}-11$, from $\mathrm{H}_{3}-29$ to $\mathrm{C}-7, \mathrm{C}-8, \mathrm{C}-9$, from $\mathrm{H}_{3}-30$ to $\mathrm{C}-5$, C-6, C-7, from $\mathrm{H}_{3}-31$ to $\mathrm{C}-2$ and C-3, from $\mathrm{H}-21$ to C-19, H-20 to C-18, from H-19 to C-17, from $\mathrm{H}_{3}-23$ to $\mathrm{C}-21$ established the linkage of $\mathrm{C}-2-\mathrm{C}-22$. The carbonyl group was connected with $\mathrm{C}-2$ by the HMBC corrections from $\mathrm{H}-2$ and $\mathrm{H}_{3}-31$ to $\mathrm{C}-1\left(\delta_{\mathrm{C}} 175.6\right)$. The correlations from $\mathrm{H}-7\left(\delta_{\mathrm{H}} 3.77 \mathrm{~d}, J=8.9 \mathrm{~Hz}\right)$ to $\mathrm{C}-3\left(\delta_{\mathrm{C}} 74.0\right)$ indicated the linkage of $\mathrm{C}-3$ and $\mathrm{C}-7$ through an oxygen atom to form a tetrahydropyran ring. Taking the molecular formula of $\mathrm{C}_{31} \mathrm{H}_{56} \mathrm{O}_{7}$ into account, four hydroxyl groups were situated at C-9, C-11, C-13, C-19, respectively, and a carboxyl group was situated at C-1. Comparison the NMR data of 1 with Zincophorin [17], a mocarboxylic acid ionophore contains one single tetrahydropyran ring, which was isolated from a strain of Streptomyces griseus, implied that $\mathbf{1}$ was identified to be an analogue of Zincophorin, the difference between two compounds was that the terminal ethyl group in Zincophorin was replaced by a $\mathrm{H}$ proton in compound 1 . On the basis of the above spectroscopic data, a gross structure of $\mathbf{1}$ was established and named Zincophorin $\mathrm{B}$, and the ${ }^{1} \mathrm{H}$ and ${ }^{13} \mathrm{C}$ resonances in $\mathbf{1}$ were assigned (Table 2).

Table 2. ${ }^{1} \mathrm{H}$ and ${ }^{13} \mathrm{C}$ NMR data of compound 1 in $\mathrm{CDCl}_{3}$.

\begin{tabular}{cccccc}
\hline No. & $\delta_{\mathbf{H}}(\boldsymbol{J}$ in Hz) & $\delta_{\mathbf{C}}$ (p.p.m) & No. & $\delta_{\mathbf{H}}(\boldsymbol{J}$ in Hz) & $\delta_{\mathbf{C}}$ (p.p.m) \\
\hline 1 & & 175.6 & 16 & $5.52 \mathrm{~m}$ & 132.4 \\
2 & $3.28 \mathrm{~m}$ & 37.1 & 17 & $5.36 \mathrm{~m}$ & 134.5 \\
3 & $4.07 \mathrm{~m}$ & 74.0 & 18 & $2.27 \mathrm{~m}$ & 42.2 \\
& & 24.9 & 19 & $3.58 \mathrm{~d}(9.2)$ & 81.7 \\
$5 \mathrm{a}$ & $1.67 \mathrm{~m}$ & 27.1 & 20 & & 132.3 \\
$5 \mathrm{~b}$ & $1.28 \mathrm{~m}$ & & 21 & $5.20 \mathrm{~d}(8.9)$ & 136.6 \\
6 & $1.40 \mathrm{~m}$ & 26.1 & 22 & $2.59 \mathrm{~m}$ & 26.1 \\
7 & $1.52 \mathrm{~m}$ & 76.1 & 23 & $0.97 \mathrm{~d}(6.6)$ & 22.9 \\
8 & $3.77 \mathrm{~d}(8.9)$ & 33.0 & 24 & $0.98 \mathrm{~d}(6.5)$ & 22.9 \\
9 & $2.04 \mathrm{~m}$ & & & $1.63 \mathrm{~s}$ & 10.1 \\
10 & $3.72 \mathrm{dd}$ & 84.3 & 25 & $0.86 \mathrm{~d}(6.7)$ & 16.7 \\
11 & $2.6,2.1)$ & 36.5 & 26 & $1.15 \mathrm{~d}(7.2)$ & 10.8 \\
12 & $3.49 \mathrm{~m}$ & 83.3 & 27 & $0.70 \mathrm{~d}(6.7)$ & 12.3 \\
13 & $1.75 \mathrm{~m}$ & 36.0 & 28 & $1.11 \mathrm{~d}(7.0)$ & 11.3 \\
$14 \mathrm{a}$ & $4.06 \mathrm{~m}$ & 69.4 & 30 & $0.81 \mathrm{~d}(6.5)$ & 17.1 \\
$14 \mathrm{~b}$ & $1.35 \mathrm{~m}$ & 34.2 & 31 & $1.18 \mathrm{~d}(7.1)$ & 15.4 \\
$15 \mathrm{a}$ & $1.77 \mathrm{~m}$ & & & & \\
$15 \mathrm{~b}$ & $2.13 \mathrm{~m}$ & 28.6 & & & \\
\hline
\end{tabular}




\subsection{Biological Activity}

The cytotoxic activities of compounds 1-8 against K562, HCT-116, and HepG2 cancer cell lines are showed in Table 3. Eight compounds restrained proliferation of the tested cells and compound 1 showed the highest cytotoxic activity, and the average $\mathrm{IC}_{50}$ values were lower than $10.0 \mu \mathrm{g} / \mathrm{mL}$.

Table 3. The cytotoxicity of compounds $1-8$.

\begin{tabular}{cccc}
\hline \multirow{2}{*}{ Compound } & \multicolumn{3}{c}{ IC $_{\mathbf{5 0}}(\boldsymbol{\mu g} / \mathbf{m L})$} \\
\cline { 2 - 4 } & K562 & HCT-116 & HepG2 \\
\hline 1 & $8.8 \pm 1.5$ & $9.5 \pm 0.8$ & $9.6 \pm 5.6$ \\
2 & $57.1 \pm 7.3$ & $75.42 \pm 2.1$ & - \\
3 & - & $68.39 \pm 3.3$ & $53.78 \pm 6.7$ \\
4 & - & $36.8 \pm 5.6$ & $17.5 \pm 1.9$ \\
5 & $28.3 \pm 1.1$ & $14.3 \pm 1.6$ & $27.3 \pm 5.8$ \\
6 & $36.6 \pm 2.4$ & $21.6 \pm 4.1$ & $79.7 \pm 5.9$ \\
7 & - & $112.3 \pm 5.7$ & - \\
8 & $11.42 \pm 3.05$ & $15.13 \pm 1.76$ & $10.83 \pm 3.47$ \\
Doxorubicin & $1.1 \pm 0.1$ & $0.9 \pm 0.3$ & $2.1 \pm 0.2$ \\
\hline
\end{tabular}

The result of minimum inhibitory concentrations (MICs) showed that compound 1 showed good activities against Gram-positive bacteria Staphylococcus aureus, Sarcina lutea, and Bacillus subtilis, and the Gram-negative bacteria Klebsiella pneumoniae in vitro (Table 4). Compound 8 showed weak antibacterial activity against two Gram-positive bacterium and the minimum inhibitory concentrations (MICs) of compounds 2-7 were determined to be $>10 \mathrm{mg} / \mathrm{mL}$, so they had no activity against these tested pathogens.

Table 4. The antibacterial activity of compounds 1-8.

\begin{tabular}{cccccc}
\hline & \multicolumn{4}{c}{ MIC $(\mu \mathrm{g} / \mathrm{mL})$} \\
\cline { 2 - 6 } Compounds & \multicolumn{3}{c}{ Gram-Positive Bacteria } & Gram-Negative Bacteria \\
\cline { 2 - 6 } & $\begin{array}{c}\text { Staphylococcus } \\
\text { aureus }\end{array}$ & Sarcina lutea & $\begin{array}{c}\text { Bacillus } \\
\text { subtilis }\end{array}$ & $\begin{array}{c}\text { Klebsiella } \\
\text { pneumonie }\end{array}$ & $\begin{array}{c}\text { Escherichia } \\
\text { coli }\end{array}$ \\
\hline $\mathbf{1}$ & $31.0 \pm 2.5$ & $44.0 \pm 5.8$ & $3.5 \pm 0.5$ & $25.0 \pm 1.5$ & - \\
$\mathbf{2 - 7}$ & - & - & - & - & - \\
\hline 8 & $210.0 \pm 20.0$ & $190.0 \pm 15.0$ & - & - & - \\
\hline
\end{tabular}

\section{Discussion}

In this research, the results of morphological, physiological, and biochemical tests showed that strain NEAU-wh3-1 has typical characteristics of the genus Embleya [41]. Such as containing LL-diaminopimelic acid as the cell wall peptidoglycan, MK-9 $\left(\mathrm{H}_{4}\right)$, and MK-9 $\left(\mathrm{H}_{6}\right)$ as the major menaquinones, phosphatidylethanolamine (PE) as the predominant phospholipid and arabinose in the whole sugars. Moreover, strain NEAU-wh3-1 formed spiral spore chains and the spore surface was rough, which are consistent with E. scabrispora DSM $41855^{\mathrm{T}}$ and E. hyalina MB891-A1 ${ }^{\mathrm{T}}$ [39,41]. In addition, the phylogenetic trees constructed from the 16S rRNA gene sequences and the concatenated sequences alignment (1979 bp) of five housekeeping genes all suggested that the isolate should be assigned to the genus Embleya.

However, some obvious differences could also be found between strain NEAU-wh3-1 and its closely related strains regarding several phenotypic and chemotaxonomic characteristics (Table 1). The isolate was able to grow at $4{ }^{\circ} \mathrm{C}$, in contrast to its closely related strains, which were not. The composition of phospholipids and menaquinones of strain NEAU-wh3-1 was also different from its related species, E. scabrispora DSM 41855 ${ }^{\mathrm{T}}$, E. hyalina MB891-A1 ${ }^{\mathrm{T}}$ and S. lasii 5H-CA11 ${ }^{\mathrm{T}}$. Most notably, the whole-cell sugars of strain NEAU-wh3-1 was found to contain arabinose, glucose, and ribose, 
while E. scabrispora DSM $41855^{\mathrm{T}}$ only contains arabinose, E. hyalina MB891-A1 ${ }^{\mathrm{T}}$ contains arabinose and glucose and $S$. lasii $5 \mathrm{H}-\mathrm{CA} 11^{\mathrm{T}}$ contains glucose and ribose, which also could distinguish the strain from its closely related strains. Other phenotypic differences include the temperature and $\mathrm{pH}$ range of growth, patterns of carbon and nitrogen utilization, hydrolysis of cellulose, starch, and Tweens $(20,40$, and 80), liquefaction of gelatin, peptonization of milk, production of $\mathrm{H}_{2} \mathrm{~S}$, and urease and reduction of nitrate. Therefore, it is evident from the phenotypic, genotypic, and chemotaxonomic data that strain NEAU-wh3-1 may represent a novel species of the genus Embleya.

The genus Embleya, recently transferred from genus Streptomyces, is a new member of the family Streptomycetaceae $[39,40]$. At present, it contains only two species: Embleya scabrispora, could produce hitachimycin with antitumor, antibacterial, and antiprotozoal activities [44-46]; and Embleya hyaline, could produce nybomycin which is an effective agent against antibiotic-resistant Staphylococcus aureus and is called a reverse antibiotic [48]. During the study of the chemical properties of the active ingredients of strain NEAU-wh3-1, eight active compounds were obtained, including one macrolide dilactone, five piericidins, one $\beta$-hydroxy acetamides, an analogue of monocarboxylic acid ionophore, which were observed to fit into at least three types based on their molecular skeletons. This shows to some extent that this strain has the ability to produce metabolites with a wide variety of different skeletal structures. Out of these compounds, Piericidins (3-7) were a class of polyene alpha-pyridone heterocyclic antibiotics, among them, Piericidin A1(5) was first reported [81], which was isolated from Streptomyces mobaraensis. Piericidins exhibit interesting biological activities, in particular antitrypanosomal [82]. In our research, compounds 3-7 exhibited different degrees of cytotoxicity on three types of tumor cells, but they did not show any antibacterial activity, which was consistent with previous reports [78,81]. As a Piericidins-producing strain, NEAU-wh3-1 has certain application potential in pest control. Conglobatin (2) is an unusual 16-membered macrocyclic diolide originally isolated from a polyether-producing strain of Streptomyces conglobatus ATCC $31005^{\mathrm{T}}$ and was reported to be essentially devoid of antifungal, antibacterial, antitumor, and antiprotozoal activity at that time [75]. However, in recent research, FW-04-806 is identical in structure to conglobatin, and it has been reported to inhibit the growth of a human chronic myelocytic leukemia K562 cell line with an $\mathrm{IC}_{50}$ of $6.66 \mu \mathrm{g} / \mathrm{mL}$, further study also investigated the effects of FW-04-806 on SKBR3 and MCF-7, respectively [83]. Its mechanism of action appears to be novel, via direct binding to the $\mathrm{N}$-terminal domain of Hsp90 and disruption of its interaction with co-chaperone Cdc37 [84]. In our antitumor activity test, Conglobatin (2) showed good bioactivity against two tumor cell lines, supporting it at least partially accounted for the cytotoxic activity of the strain NEAU-wh3-1 extract. BE-52211 D (8) was a cytotoxic metabolite from a strain of Streptomyces and had been reported to have moderate cytotoxicity against human hepatocellular liver carcinoma cells HepG2, human leukemia cells K562, and human colon carcinoma cells HCT- 116 with the $\mathrm{IC}_{50}$ values of $>10 \mu \mathrm{g} / \mathrm{mL}$ [80], which is consistent with the result in the present study. Compound 1 structurally related to zincophorin, which was also referred to as M144255 or griseochellin and is a polyoxygenated ionophoric antibiotic isolating from Streptomyces griseus in 1984 [17]. It has been reported to possess strong in vivo activity against Gram-positive bacteria and have strong cytotoxicity against human lung carcinoma cells A549 and Madin-Darby canine kidney cells MDCK [18]. No biological activity has been reported against Gram-negative bacteria, yeasts, and fungi [85]. The second member in the zincophorin family named CP-78545, was found in the culture broth of Streptomyces sp. N731-45. The structural difference between them is that CP-78545 has an extra terminal double bond; but they have similar spectrum and potency on biological properties except for the antitumor activity (no reports) [86]. In our antitumor and antimicrobial assays, compound $\mathbf{1}$ showed the highest antitumor activity against three human cell lines and good antibacterial activity against Gram-negative bacteria. To our knowledge, this is the first report of this kind of compound with antibacterial activity against Gram-negative bacteria. This study has enriched the activity spectrum of Zincophorins. 


\section{Conclusions}

Strain producing a new compound with strong antitumor activity, isolated from the rhizosphere soil of wheat (Triticum aestivum L.) in HeBei province, China. Morphological and chemotaxonomic features together with phylogenetic analysis suggested that strain NEAU-wh3-1 belonged to the genus Embleya. Cultural and biochemical characteristics combined with multilocus sequence analysis clearly revealed that strain NEAU-wh3-1 may represent a novel species of the genus Embleya. Moreover, eight compounds, including one new compound with higher antitumor activities against three human cell lines, were isolated from the strain.

Supplementary Materials: The following are available online at http://www.mdpi.com/2076-2607/8/3/441/s1, Table S1: GenBank accession numbers of the sequences used in MLSA; Table S2: MLSA distance values for selected strains in this study; Figure S1: The polar lipids of strain NEAU-wh3-1; Figure S2: Maximum-likelihood tree based on 16S rRNA gene sequences showing relationship between strain NEAU-wh3-1 and related taxa; Figure S3: Maximum-likelihood tree based on multilocus sequence analysis (MLSA)analysis of the concatenated partial sequences (1979 bp) from five housekeeping genes ( $\operatorname{tat} D$, gyrB, rec $A, r p o B$, and $\operatorname{trp} B$ ) of strain NEAU-wh3-1 (in bold) with related taxa; Figure S4: ${ }^{1} \mathrm{H}$ NMR $(400 \mathrm{MHz})$ spectrum of compound 1 in $\mathrm{CDCl}_{3}$; Figure S5: ${ }^{13} \mathrm{C}$ NMR (150 $\mathrm{MHz}$ ) spectrum of compound $\mathbf{1}$ (in $\left.\mathrm{CDCl}_{3}\right)$; Figure $\mathrm{S}:{ }^{1} \mathrm{H}-{ }^{1} \mathrm{H}$ COSY spectrum $\left(400 \mathrm{MHz}\right.$ ) of compound $\mathbf{1}\left(\right.$ in $\left.\mathrm{CDCl}_{3}\right)$; Figure S7: HSQC spectrum $(400 \mathrm{MHz})$ of compound 1 (in $\left.\mathrm{CDCl}_{3}\right)$; Figure S8: HMBC spectrum $(400 \mathrm{MHz})$ of compound 1 (in $\mathrm{CDCl}_{3}$ ); Figure S9: IR spectrum of compound 1(in EtOH); Figure S10: UV spectrum of compound 1 (in EtOH); Figure S11: The HRESIMS spectrum of compound 1; Figure S12: ${ }^{1} \mathrm{H}$ NMR $(400 \mathrm{MHz})$ spectrum of compound 2 in $\mathrm{CDCl}_{3}$; Figure S13: ${ }^{13} \mathrm{C}$ NMR $(150 \mathrm{MHz})$ spectrum of compound 2 in $\mathrm{CDCl}_{3}$; Figure S14: The ESI-MS spectrum of compound 2; Figure S15: ${ }^{1} \mathrm{H}$ NMR (400 MHz) spectrum of compound 3 in $\mathrm{CDCl}_{3}$; Figure S16: The ESI-MS spectrum of compound 3; Figure S17: ${ }^{1} \mathrm{H}$ NMR (400 MHz) spectrum of compound 4 in $\mathrm{CDCl}_{3}$; Figure S18: The ESI-MS spectrum of compound 4; Figure S19: ${ }^{1} \mathrm{H}$ NMR (400 MHz) spectrum of compound 5 in $\mathrm{CDCl}_{3}$; Figure S20: The ESI-MS spectrum of compound 5; Figure S21: ${ }^{1} \mathrm{H}$ NMR (400 MHz) spectrum of compound 6 in $\mathrm{CDCl}_{3}$; Figure S22: The ESI-MS spectrum of compound 6; Figure S23: ${ }^{1} \mathrm{H}$ NMR (400 MHz) spectrum of compound 7 in $\mathrm{CDCl}_{3}$; Figure S24: ESI-MS spectrum of compound of compound 7; Figure S25: ${ }^{1} \mathrm{H}$ NMR (400 MHz) spectrum of compound 8 in $\mathrm{CDCl}_{3}$; Figure S26: ${ }^{13} \mathrm{C}$ NMR $(150 \mathrm{MHz})$ spectrum of compound 8 in $\mathrm{CDCl}_{3}$; Figure S27: The HRESIMS spectrum of compound 8.

Author Contributions: H.W., T.S., and W.S. performed the experiments. X.G. prepared the figures and tables. P.C. and X.X. analyzed the data. Y.S. and J.Z. designed the experiments and reviewed the manuscript. All authors have read and agreed to the published version of the manuscript.

Funding: This work was supported in part by grants from the Heilongjiang Postdoctoral Fund (LBH-Z17015) and the Scientific Research Foundation for Settled Postdoctoral of Heilongjiang Province (LBH-Q19082).

Conflicts of Interest: The authors declare that there are no conflict of interest.

\section{References}

1. Torre, L.A.; Bray, F.; Siegel, R.L.; Ferlay, J.; Lortet-Tieulent, J.; Jemal, A. Global cancer statistics, 2012. CA. Cancer J. Clin. 2015, 65, 87-108. [CrossRef]

2. Commander, H.; Whiteside, G.; Perry, C. Vandetanib: First global approval. Drugs 2011, 71, $1355-1365$. [CrossRef]

3. Zhu, F.; Zhao, X.; Li, J.; Guo, L.; Bai, L.; Qi, X. A new compound Trichomicin exerts antitumor activity through STAT3 signaling inhibition. Biomed. Pharmacother. 2020, 121, 109608. [CrossRef]

4. Zhang, Z.; Yu, X.; Wang, Z.; Wu, P.; Huang, J. Anthracyclines potentiate anti-tumor immunity: A new opportunity for chemoimmunotherapy. Cancer Lett. 2015, 369, 331-335. [CrossRef]

5. Sznarkowska, A.; Kostecka, A.; Meller, K.; Bielawski, K.P. Inhibition of cancer antioxidant defense by natural compounds. Oncotarget 2017, 8, 15996-16016. [CrossRef]

6. Newman, D.J.; Cragg, G.M. Natural products as sources of new drugs over the last 25 years. J. Nat. Prod. 2007, 70, 461-477. [CrossRef]

7. Cragg, G.M.; Newman, D.J.; Snader, K.M. Natural products in drug discovery and development. J. Nat. Prod. 1997, 60, 52-60. [CrossRef]

8. Chin, Y.W.; Balunas, M.J.; Chai, H.B.; Kinghorn, A.D. Drug discovery from natural sources. Drug Addict. From Basic Res. Ther. 2008, 8, 17-39. 
9. Pettit, R.K. Culturability and Secondary Metabolite Diversity of Extreme Microbes: Expanding Contribution of Deep Sea and Deep-Sea Vent Microbes to Natural Product Discovery. Mar. Biotechnol. 2011, 13, 1-11. [CrossRef]

10. Qin, S.; Li, J.; Chen, H.H.; Zhao, G.Z.; Zhu, W.Y.; Jiang, C.L.; Xu, L.H.; Li, W.J. Isolation, diversity, and antimicrobial activity of rare actinobacteria from medicinal plants of tropical rain forests in Xishuangbanna China. Appl. Environ. Microbiol. 2009, 75, 6176-6186. [CrossRef]

11. Parkinson, D.R.; Arbuck, S.G.; Moore, T.; Pluda, J.M.; Christian, M.C. Clinical development of anticancer agents from natural products. Stem Cells 1994, 12, 30-43. [CrossRef]

12. Berdy, J. Bioactive microbial metabolites. J Antibiot. 2005, 58, 1-26. [CrossRef]

13. Ventura, M.; Canchaya, C.; Tauch, A.; Chandra, G.; Fitzgerald, G.F.; Chater, K.F.; van Sinderen, D. Genomics of Actinobacteria: Tracing the Evolutionary History of an Ancient Phylum. Microbiol. Mol. Biol. Rev. 2007, 71, 495-548. [CrossRef]

14. Goodfellow, M.; Williams, S.T. Ecology of actinomycetes. Annu. Rev. Microbiol. 1983, 37, 189-216. [CrossRef]

15. Rabbani, A.; Finn, R.M.; Ausió, J. The anthracycline antibiotics: Antitumor drugs that alter chromatin structure. BioEssays 2005, 27, 50-56. [CrossRef]

16. Demain, A.L.; Sanchez, S. Microbial drug discovery: 80 Years of progress. J. Antibiot. 2009, 62, 5-16. [CrossRef]

17. Brooks, H.A.; Gardner, D.; Poyser, J.P.; King, T.J. The structure and absolute stereochemistry of zincophorin (antibiotic m144255): a monobasic carboxylic acid ionophore having a remarkable specificity for divalent cations. J. Antibiot. 1984, 37(11), 1501-1504. [CrossRef]

18. Walther, E.; Boldt, S.; Kage, H.; Lauterbach, T.; Martin, K.; Roth, M.; Hertweck, C.; Sauerbrei, A.; Schmidtke, M.; Nett, M. Zincophorin-biosynthesis in Streptomyces griseus and antibiotic properties. GMS Infect. Dis. 2016, 4, Doc08.

19. Yang, S.X.; Gao, J.M.; Zhang, A.L.; Laatsch, H.S. A novel toxic macrolactam polyketide glycoside produced by actinomycete Streptomyces sannanensis. Bioorg. Med. Chem. Lett. 2011, 21, 3905-3908. [CrossRef]

20. Subramani, R.; Aalbersberg, W. Culturable rare Actinomycetes: Diversity, isolation and marine natural product discovery. Appl. Microbiol. Biotechnol. 2013, 97, 9291-9321. [CrossRef]

21. Heidari, B.; Mohammadipanah, F. Isolation and identification of two alkaloid structures with radical scavenging activity from Actinokineospora sp. UTMC 968, a new promising source of alkaloid compounds. Mol. Biol. Rep. 2018, 45, 2325-2332. [CrossRef] [PubMed]

22. Gao, M.Y.; Qi, H.; Li, J.S.; Zhang, H.; Zhang, J.; Wang, J.D.; Xiang, W.S. A new polysubstituted cyclopentene derivative from Streptomyces sp. HS-NF-1046. J. Antibiot. 2017, 70, 216-218. [CrossRef] [PubMed]

23. Peláez, F. The historical delivery of antibiotics from microbial natural products - Can history repeat? Biochem. Pharmacol. 2006, 71, 981-990. [CrossRef]

24. Kekuda, P.; Onkarappa, R.; Jayanna, N. Characterization and Antibacterial Activity of a Glycoside Antibiotic from Streptomyces variabilis PO-178. Sci. Technol. Arts. Res. J. 2015, 3, 116. [CrossRef]

25. Miao, V.; Davies, J. Actinobacteria: The good, the bad, and the ugly. Antonie van Leeuwenhoek 2010, 98, 143-150. [CrossRef]

26. Subramani, R.; Aalbersberg, W. Marine actinomycetes: An ongoing source of novel bioactive metabolites. Microbiol. Res. 2012, 167, 571-580. [CrossRef]

27. Clardy, J.; Fischbach, M.A.; Walsh, C.T. New antibiotics from bacterial natural products. Nat. Biotechnol. 2006, 24, 1541-1550. [CrossRef]

28. Ayed, A.; Slama, N.; Mankai, H.; Bachkouel, S.; ElKahoui, S.; Tabbene, O.; Limam, F. Streptomyces tunisialbus sp. nov., a novel Streptomyces species with antimicrobial activity. Antonie van Leeuwenhoek 2018, 111, 1571-1581. [CrossRef]

29. Mccully, M.; Harper, J.D.I.; An, M.; Kent, J.H. The rhizosphere: the key functional unit in plant soil microbial interactions in the field implications for the understanding of allelopathic effects. Pol. J. Vet. Sci. 2005, 15, 493-498.

30. Hiltner, L. Uber neuer erfahrungen und probleme auf dem gebiet der berücksichtigung unter besonderer berücksichtigung der gründüngung und brache. Arbeiten der Deustchen Landwirtschaftsgesellesschaft 1904, 32, 1405-1417.

31. Berendsen, R.L.; Pieterse, C.M.J.; Bakker, P.A.H.M. The rhizosphere microbiome and plant health. Trends. Plant Sci. 2012, 17, 478-486. [CrossRef] 
32. Loper, J.E.; Gross, H. Genomic analysis of antifungal metabolite production by Pseudomonas fluorescens Pf-5. Eur. J. Plant Pathol. 2007, 119, 265-278. [CrossRef]

33. Reiter, B.; Sessitsch, A.; Nowak, J.; Cle, C. Endophytic colonization of Vitis vinifera L. by plant growth-promoting bacterium Burkholderia sp. strain PsJN. Society 2005, 71, 1685-1693.

34. Lanteigne, C.; Gadkar, V.J.; Wallon, T.; Novinscak, A.; Filion, M. Production of DAPG and HCN by Pseudomonas sp. LBUM300 contributes to the biological control of bacterial canker of tomato. Phytopathology 2012, 102, 967-973. [CrossRef]

35. Osei, E.; Kwain, S.; Mawuli, G.T.; Anang, A.K.; Owusu, K.B.A.; Camas, M.; Camas, A.S.; Ohashi, M.; Alexandru-Crivac, C.N.; Deng, H. Paenidigyamycin A, potent antiparasitic imidazole alkaloid from the ghanaian Paenibacillus sp. De2Sh. Mar. Drugs 2019, 17, 9. [CrossRef]

36. Mukhtar, S.; Mehnaz, S.; Mirza, M.S.; Malik, K.A. Isolation and characterization of bacteria associated with the rhizosphere of halophytes (Salsola stocksii and Atriplex amnicola) for production of hydrolytic enzymes. Brazilian J. Microbiol. 2019, 50, 85-97. [CrossRef]

37. Orfali, R.; Perveen, S. Secondary metabolites from the Aspergillus sp. in the rhizosphere soil of Phoenix dactylifera (Palm tree). BMC Chem. 2019, 13, 1-6. [CrossRef]

38. Wang, R.J.; Zhang, S.Y.; Ye, Y.H.; Yu, Z.; Qi, H.; Zhang, H.; Xue, Z.L.; Wang, J.D.; Wu, M. Three new isoflavonoid glycosides from the mangrove-derived actinomycete micromonospora aurantiaca 110B. Mar. Drugs 2019, 17, 294. [CrossRef]

39. Nouioui, I.; Carro, L.; García-López, M.; Meier-Kolthoff, J.P.; Woyke, T.; Kyrpides, N.C.; Pukall, R.; Klenk, H.-P.; Goodfellow, M.; Göker, M. Genome-Based Taxonomic Classification of the Phylum Actinobacteria. Front. Microbiol. 2018, 9, 2007. [CrossRef]

40. Oren, A.; Garrity, G.M. List of new names and new combinations previously effectively, but not validly, published. Int. J. Syst. Evol. Microbiol. 2018, 68, 2707-2709. [CrossRef]

41. Komaki, H.; Hosoyama, A.; Kimura, A.; Ichikawa, N.; Igarashi, Y.; Tamura, T. Classification of 'Streptomyces hyalinum' Hamada and Yokoyama as Embleya hyalina sp. nov., the second species in the genus Embleya, and emendation of the genus Embleya. Int. J. Syst. Evol. Microbiol. 2020, 1-5. [CrossRef]

42. Kämpfer, P.; Genus, I. Streptomyces Waksman and Henrici 1943, 339 AL. In Bergey's Manual of Systematic Bacteriology, 2nd ed.; Springer: New York, NY, USA, 2012; pp. 1679-1680.

43. Ping, X.; Takahashi, Y.; Seino, A.; Iwai, Y.; Omura, S. Streptomyces scarbrisporus sp. nov. Int. J. Syst. Evol. Microbiol. 2004, 54, 577-581. [CrossRef]

44. Omura, S.; Nakagawa, A.; Shibata, K.; Sano, H. The structure of hitachimycin, a novel macrocyclic lactam involving $\beta$-phenylalanine. Tetrahedron Lett. 1982, 23, 4713-4716. [CrossRef]

45. Komiyama, K.; Edanami, K.I.; Yamamoto, H.; Umezawa, I. Antitumor activity of a new antitumor antibiotic, stubomycin. J. Antibiot. 1982, 35, 703-706. [CrossRef]

46. Shibata, K.; Satsumabayashi, S.; Sano, H.; Komiyama, K.; Nakagawa, A.; Omura, S. Chemical modification of hitachimycin. Synthesis, antibacterial, cytocidal and in vivo antitumor activities of hitachimycin derivatives. J. Antibiot. 1988, 41, 614-623. [CrossRef]

47. Naganawa, H.; Wakashiro, T.; Yagi, A.; Kondo, S.; Takita, T.; Hamada, M.; Maeda, K.; Umezawa, H. Deoxynybomycin from a streptomyces. J. Antibiot. 1970, 23, 365-368. [CrossRef]

48. Hiramatsu, K.; Igarashi, M.; Morimoto, Y.; Baba, T.; Umekita, M.; Akamatsu, Y. Curing bacteria of antibiotic resistance: Reverse antibiotics, a novel class of antibiotics in nature. Int. J. Antimicrob. Agents 2012, 39, 478-485. [CrossRef]

49. Hayakawa, M.; Nonomura, H. Humic acid-vitamin agar, a new medium for the selective isolation of soil actinomycetes. J. Ferment. Technol. 1987, 65, 501-509. [CrossRef]

50. Shirling, E.B.; Gottlieb, D. Methods for characterization of Streptomyces species. Int. J. Syst. Bacteriol. 1966, 16, 313-340. [CrossRef]

51. Vichai, V.; Kirtikara, K. Sulforhodamine B colorimetric assay for cytotoxicity screening. Nat. Protoc. 2006, 1, 1112-1116. [CrossRef]

52. Jin, L.; Zhao, Y.; Song, W.; Duan, L.; Jiang, S.; Wang, X.; Zhao, J.; Xiang, W. Streptomyces inhibens sp. Nov., a novel actinomycete isolated from rhizosphere soil of wheat (Triticum aestivum L.). Int. J. Syst. Evol. Microbiol. 2019, 69, 688-695. [CrossRef] [PubMed] 
53. Zhao, J.W.; Han, L.Y.; Yu, M.Y.; Cao, P.; Li, D.M.; Guo, X.W.; Liu, Y.Q.; Wang, X.J.; Xiang, W.S. Characterization of Streptomyces sporangiiformans sp. nov., a Novel Soil Actinomycete with Antibacterial Activity against Ralstonia solanacearum. Microorganisms 2019, 7, 360. [CrossRef] [PubMed]

54. Smibert, R.M.; Krieg, N.R. Phenotypic characterization. In Methods for General and Molecular Bacteriology, 2nd ed.; Gerhardt, P., Murray, R.G.E., Wood, W.A., Krieg, N.R., Eds.; American Society for Microbiology: Washington, DC, USA, 1994; pp. 607-654.

55. Gordon, R.E.; Barnett, D.A.; Handerhan, J.E.; Pang, C. Nocardia coeliaca, Nocardia autotrophica, and the nocardin strain. Int. J. Syst. Bacteriol. 1974, 24, 54-63. [CrossRef]

56. Yokota, A.; Tamura, T.; Hasegawa; Huang, L.H. Catenuloplanes japonicas gen. nov., sp. nov., nom. rev., a new genus of the order Actinomycetales. Int. J. Syst. Bacteriol. 1993, 43, 805-812. [CrossRef]

57. Lechevalier, M.P.; Lechevalier, H.A. The chemotaxonomy of actinomycetes. In Actinomycete taxonomy, 2nd ed.; Dietz, A., Thayer, D.W., Eds.; special publication for Society of Industrial Microbiology: Arlington, TX, USA, 1980; pp. 227-291.

58. Minnikin, D.E.; O’Donnell, A.G.; Goodfellow, M.; Alderson, G.; Athalye, M.; Schaal, A.; Parlett, J.H. An integrated procedure for the extraction of bacterial isoprenoid quinones and polar lipids. J. Microbiol. Methods 1984, 2, 233-241. [CrossRef]

59. Collins, M.D. Isoprenoid quinone analyses in bacterial classification and identification. In Chemical methods in bacterial systematics; Goodfellow, M., Minnikin, D.E., Eds.; Academic Press: London, UK, 1985; pp. 267-284.

60. Shen, Y.; Sun, T.; Jiang, S.; Mu, S.; Li, D.; Guo, X.; Zhang, J.; Zhao, J.; Xiang, W. Streptomyces lutosisoli sp. nov., a novel actinomycete isolated from muddy soil. Antonie Van Leeuwenhoek, Int. J. Gen. Mol. Microbiol. 2018, 111, 2403-2412. [CrossRef]

61. Wu, C.; Lu, X.; Qin, M.; Wang, Y.; Ruan, J. Analysis of menaquinone compound in microbial cells by HPLC. Microbiology 1989, 16, 176-178.

62. Kim, S.B.; Brown, R.; Oldfield, C.; Gilbert, S.C.; Iliarionov, S.; Goodfellow, M. Gordonia amicalis sp. nov., a novel dibenzothiophene-desulphurizing actinomycete. Int. J. Syst. Evol. Microbiol. 2000, 50, 2031-2036. [CrossRef]

63. Yoon, S.H.; Ha, S.M.; Kwon, S.; Lim, J.; Kim, Y.; Seo, H.; Chun, J. Introducing EzBioCloud: A taxonomically united database of $16 \mathrm{~S}$ rRNA gene sequences and whole-genome assemblies. Int. J. Syst. Evol. Microbiol. 2017, 67, 1613-1617. [CrossRef]

64. Saitou, N.; Nei, M. The neighbor-joining method: a new method for reconstructing phylogenetic trees. Mol. Biol. Evol. 1987, 4, 406-425.

65. Felsenstein, J. Evolutionary trees from DNA sequences: A maximum likelihood approach. J. Mol. Evol. 1981, 17, 368-376. [CrossRef] [PubMed]

66. Kumar, S.; Stecher, G.; Tamura, K. Mega7: molecular evolutionary genetics analysis version 7.0 for bigger datasets. Mol. Biol. Evol. 2016, 33, 1870-1874. [CrossRef] [PubMed]

67. Felsenstein, J. Confidence Limits on Phylogenies: an Approach Using the Bootstrap. Evolution (N. Y). 1985, 39, 783-791.

68. Kimura, M. A simple method for estimating evolutionary rates of base substitutions through comparative studies of nucleotide sequences. J. Mol. Evol. 1980, 16, 111-120. [CrossRef]

69. Hatano, K.; Nishii, T.; Kasai, H. Taxonomic re-evaluation of whorl-forming Streptomyces (formerly Streptoverticillium) species by using phenotypes, DNA-DNA hybridization and sequences of gyrB, and proposal of Streptomyces luteireticuli (ex Katoh and Arai 1957) corrig., sp. nov., nom. rev. Int. J. Syst. Evol. Microbiol. 2003, 53, 1519-1529. [CrossRef]

70. Guo, Y.P.; Zheng, W.; Rong, X.Y.; Huang, Y. A multilocus phylogeny of the Streptomyces griseus 16S rRNA gene clade: Use of multilocus sequence analysis for streptomycete systematics. Int. J. Syst. Evol. Microbiol. 2008, 58, 149-159. [CrossRef]

71. Wang, J.; Zhang, H.; Ying, L.; Wang, C.; Jiang, N.; Zhou, Y.; Wang, H.; Bai, H. Five new epothilone metabolites from Sorangium cellulosum strain So0157-2. J. Antibiot. 2009, 62, 483-487. [CrossRef]

72. Wayne, P.A. Clinical and Laboratory Standards Institute. Methods for dilution antimicrobial susceptibility tests for bacteria that grow aerobically; approved standard-ninth edition. Clin. Lab. Standards Institute 2012, $32,2$. 
73. Liu, C.; Han, C.; Jiang, S.; Zhao, X.; Tian, Y.; Yan, K.; Wang, X.; Xiang, W. Streptomyces lasii sp. nov., a Novel Actinomycete with Antifungal Activity Isolated from the Head of an Ant (Lasius flavus). Curr. Microbiol. 2018, 75, 353-358. [CrossRef]

74. Rong, X.; Huang, Y. Taxonomic evaluation of the Streptomyces hygroscopicus clade using multilocus sequence analysis and DNA-DNA hybridization, validating the MLSA scheme for systematics of the whole genus. Syst. Appl. Microbiol. 2012, 35, 7-18. [CrossRef]

75. Westley, J.W.; Liu, C.M.; Evans, R.H.; Blount, J.F. Conglobatin, a novel macrolide dilactone from Streptomyces conglobatus ATCC 31005. J. Antibiot. 1979, 32, 874-877. [CrossRef]

76. Yoshida, S.; Yoneyama, K.; Shiraishi, S.; Watanabe, A.; Takahashi, N. Chemical structures of new piericidins produced by Streptomyces pactum. Agric. Biol. Chem. 1977, 41, 855-862. [CrossRef]

77. Kubota, N.K.; Ohta, E.; Ohta, S.; Koizumi, F.; Suzuki, M.; Ichimura, M.; Ikegami, S. Piericidins C5 and C6: New 4-pyridinol compounds produced by Streptomyces sp. and Nocardioides sp. Bioorganic Med. Chem. 2003, 11, 4569-4575. [CrossRef]

78. Tamura, S.; Takahashi, N.; Miyamoto, S.; Mori, R.; Suzuki, S.; Nagatsu, J. Isolation and physiological activities of piericidin A, a natural insecticide produced by Streptomyces. Agr. Biol. Chem. 1963, 27, 576-582. [CrossRef]

79. Kominato, K.; Watanabe, Y.; Hirano, S.I.; Kioka, T.; Tone, H. Mer-a2026a and b, novel piericidins with vasodilating effect. ii. physico-chemical properties and chemical structures. J. Antibiot. 1994, 48, 103-105. [CrossRef]

80. Wang, H.; Zhao, X.L.; Gao, Y.H.; Qi, H.; Zhang, H.; Xiang, W.S.; Wang, J.D.; Wang, X.J. Two new cytotoxic metabolites from Streptomyces sp. HS-NF-813. J. Asian. Nat. Prod. Res. 2018, 22, 249-256. [CrossRef]

81. Hall, C.; Wu, M.; Crane, F.L.; Takahashi, H.; Tamura, S.; Folkers, K. Piericidin A: A new inhibitor of mitochondrial electron transport. Biochem. Biophys. Res. Commun. 1966, 25, 373-377. [CrossRef]

82. Shaaban, K.A.; Helmke, E.; Kelter, G.; Fiebig, H.H.; Laatsch, H. Glucopiericidin C: A cytotoxic piericidin glucoside antibiotic produced by a marine Streptomyces isolate. J. Antibiot. 2011, 64, 205-209. [CrossRef]

83. Huang, W.; Ye, M.; Zhang, L.; Wu, Q.; Zhang, M.; Xu, J.; Zheng, W. FW-04-806 inhibits proliferation and induces apoptosis in human breast cancer cells by binding to N-terminus of Hsp90 and disrupting Hsp90-Cdc37 complex formation. Mol. Cancer 2014, 13, 1-13. [CrossRef]

84. Huang, W.; Wu, Q.D.; Zhang, M.; Kong, Y.L.; Cao, P.R.; Zheng, W.; Xu, J.H.; Ye, M. Novel Hsp90 inhibitor FW-04-806 displays potent antitumor effects in HER2-positive breast cancer cells as a single agent or in combination with lapatinib. Cancer Lett. 2015, 356, 862-871. [CrossRef]

85. Song, Z.; Lohse, A.G.; Hsung, R.P. Challenges in the synthesis of a unique mono-carboxylic acid antibiotic, (+)-zincophorin. Cheminform 2009, 26, 560-571. [CrossRef] [PubMed]

86. Dirlam, J.P.; Belton, A.M.; Chang, S.P.; Cullen, W.P.; Huang, L.H.; Kojima, Y.; Maeda, H.; Nishiyama, S.; Oscarson, J.R.; Sakakibara, T.; et al. Cp-78,545, a new monocarboxylic acid ionophore antibiotic related to zincophorin and produced by a streptomyces. J. Antibiot. 1989, 42, 1213-1220. [CrossRef] [PubMed] 